\title{
The millipede genus Solaenodolichopus Verhoeff, 1924 (Diplopoda, Polydesmida, Paradoxosomatidae). 1. New genus diagnosis and redescriptions of named species
}

\author{
Robert MESIBOV \\ Queen Victoria Museum and Art Gallery, Launceston, Tasmania, Australia 7250 \\ Email: mesibov@,southcom.com.au \\ urn:1sid:zoobank.org:author:24BA85AE-1266-494F-9DE5-EEF3C9815269
}

\begin{abstract}
Solaenodolichopus Verhoeff, 1924 is redefined to include S. pruvoti (Brolemann, 1931), S. rubriventris Verhoeff, 1928, S. sulcatus (Verhoeff, 1928), S. teres (Verhoeff, 1924), S. vittatus (Verhoeff, 1924 ) and S. walesius Verhoeff, 1928, each of which is redescribed. Lectotypes are designated for S. sulcatus, S. teres, S. vittatus and S. walesius. Parwalesoma Verhoeff, 1937 is synonymised with Solaenodolichopus and S. vittatus dorsalis (Verhoeff, 1924) with S. vittatus vittatus (Verhoeff, 1924).
\end{abstract}

Keywords. Millipede, Paradoxosomatidae, Queensland, New South Wales, Australia.

Mesibov R. 2014. The millipede genus Solaenodolichopus Verhoeff, 1924 (Diplopoda, Polydesmida, Paradoxosomatidae). 1. New genus diagnosis and redescriptions of named species. European Journal of Taxonomy 83: 1-36. http://dx.doi.org/10.5852/ejt.2014.83

\section{Introduction}

Solaenodolichopus Verhoeff, 1924 is an eastern Australian genus of Paradoxosomatidae with a distinctive gonopod structure and no obvious paranota on diplosegments. There are six named and many undescribed species native to Queensland (Mesibov 2008) and New South Wales (Car 2009). One of the named species, S. pruvoti (Brolemann, 1931), was first described from New Caledonia and has recently been reported from Western Australia (Car et al. 2013); more records are reported here from southeast Queensland, where S. pruvoti is likely to be native. Records of S. pruvoti from South Australia (Jeekel 1982, 2002) may be based on a misidentification (see below).

In this paper I review the history of the Solaenodolichopus genus concept, propose a new diagnosis, redescribe the six named species, designate several lectotypes, accept two previously proposed synonymies and propose two new synonymies. New species of Solaenodolichopus will be treated in future papers in this series.

\section{Materials and Methods}

'Male' and 'female' in the text refer to adult individuals. All specimens are stored in 70-80\% ethanol in their respective repositories. 
The photomicrographs in Fig. 11C and 11D were taken using an eyepiece video camera mounted on an Amscope binocular microscope. Other photomicrographs were taken with a Canon EOS 1000D digital SLR camera mounted on a Nikon SMZ800 binocular dissecting microscope equipped with a beam splitter. Measurements were made to the nearest $0.1 \mathrm{~mm}$ with the same microscope using an eyepiece grid and a reference scale. Most photomicrographs used in the figures are focus-stacked composites prepared with Zerene Stacker 1.04 software. Preliminary gonopod drawings were traced from printed copies of focus-stacked photomicrographs; details were added and corrected by reference to the actual gonopod. SEM images were acquired digitally with a FEI Quanta 600 ESEM at low vacuum using uncoated specimens which were air-dried, examined and returned to alcohol. Maps were generated using ArcView GIS 3.2. All figures were prepared using GIMP 2.8 image editing software; backgrounds in some photomicrographs have been edited to remove distracting highlights and artifacts.

Latitude/longitude figures are given with the WGS84 datum together with my estimate of the spatial uncertainty (Darwin Core coordinateUncertaintyInMeters). Data in square brackets are my additions; latitude/longitude figures not in square brackets are based on label data or the respective museum collection databases.

Details of specimen lots of the species redescribed in this paper are tabulated as an Excell file in Supplement 1.

Images of Solaenodolichopus types as alcohol specimens and slide mounts, including their labels, are compiled in a PDF file in Supplement 2.
Abbreviations
$\mathrm{AM}=$ Australian Museum, Sydney, Australia
NHRS $=$ Naturhistoriska Riksmuseet, Stockholm, Sweden
NSW $=$ New South Wales, Australia
QLD = Queensland, Australia
$\mathrm{QM}=$ Queensland Museum, Brisbane, Australia
$\mathrm{SAM}=$ South Australian Museum, Adelaide, Australia
$\mathrm{ZMB}=$ Museum für Naturkunde, Berlin, Germany
$\mathrm{ZSM}=$ Zoologische Staatssammlung München, Munich, Germany

\section{Results}

Order Polydesmida Pocock, 1887

Suborder Strongylosomatidea Brölemann, 1916

Family Paradoxosomatidae Daday, 1889

Subfamily Australiosomatinae Brölemann, 1916

Tribe Antichiropodini Brölemann, 1916

Solaenodolichopus Verhoeff, 1924

Solänodolichopus Verhoeff, 1924: 10 (in key as subgenus of Antichiropus), 11 (in key as subgenus of Antichiropus), 19 (first description).

Paraulacoporus Verhoeff, 1928: 88, 90 (in key), 91 (in key), 93. [Type species Paraulacoporus sulcatus Verhoeff, 1928, by monotypy.]

Parwalesoma Verhoeff, 1937: 139 (first description). [New synonymy. Type species Parwalesoma castaneum Verhoeff, 1937, by monotypy.] 
Solaenodolichopus - Attems 1926: 143 (in key as subgenus of Antichiropus); 1937: 260 (synonymised with Aulacoporus). - Verhoeff 1932: 1574 (as subgenus of Antichiropus), 1595 (in key), 1597 (in key). — Jeekel 1965: 8; 1968: 29 (as synonym of Aulacoporus); 1971: 233 (type species designated); 2000: 37 (in key), 40-42; 2003: 42. — Hoffman 1980: 166 (as synonym of Aulacoporus). — Nguyen \& Sierwald 2013: 1159.

Solänodolichopus - Verhoeff 1928: 88 (raised to genus), 90 (in key), 91 (in key), 94. - Brolemann 1931: 299. — Verhoeff 1937: 139. — Verhoeff 1941: 8 (in key).

Paraulacoporus - Attems 1929: 258. - Brolemann 1931: 295, 298. — Verhoeff 1932: 1595 (in key), 1598 (in key). - Attems 1937: 260 (synonymised with Aulacoporus). — Verhoeff 1941: 8 (in key). - Jeekel 1965: 8. - Jeekel 1968: 29 (as synonym of Aulacoporus). — Jeekel 1971: 230 (in genus catalogue). - Hoffman 1980: 166 (as synonym of Aulacoporus). - Jeekel 2000: 40, 42 (synonymised with Solaenodolichopus). — Nguyen \& Sierwald 2013: 1159 (as synonym of Solaenodolichopus).

Parwalesoma - Attems 1940: 549 (Verhoeff's description reworded). - Verhoeff 1941: 8 (in key). Jeekel 1965: 8. — Jeekel 1968: 29, 126. — Jeekel 1971: 231. — Hoffman 1980: 166. — Jeekel 2000: 37 (in key), 40-42. — Jeekel 2003: 42. — Nguyen \& Sierwald 2013: 1157.

\section{Type species}

Antichiropus (Solaenodolichopus) teres Verhoeff, 1924, by subsequent designation.

\section{Other assigned species}

S. pruvoti (Brolemann, 1931), S. rubriventris Verhoeff, 1928, S. sulcatus (Verhoeff, 1928), S. vittatus (Verhoeff, 1924) and S. walesius Verhoeff, 1928.

\section{History of Solaenodolichopus}

The sometimes confusing development of the Solaenodolichopus concept over the past 90 years has involved five genus names and four diplopodologists.

Besides Solaenodolichopus, some of the species redescribed in this paper have also been assigned to Antichiropus Attems, 1911, Aulacoporus Verhoeff, 1924, Paraulacoporus Verhoeff, 1928 and Parwalesoma Verhoeff, 1937.

The four diplopodologists were the Austrian Carl Attems (1868-1952, in full, Carl Aug. Graf [Count] Attems-Petzenstein), the German Karl Wilhelm Verhoeff (1867-1944), the Frenchman Henry Wilfred Brölemann (1860-1933) and the Dutchman Casimir Albrecht Willem Jeekel (1922-2010). I use the spelling 'Brolemann' below rather than 'Brölemann', following that author's practice in the 1931 publication cited in this paper. Brolemann dropped the umlaut in his name from 1920 onwards (J.-J. Geoffroy, in litt., 30 Apr. 2009).

All four specialists viewed the polydesmidan gonopod as a modified walking leg on which it was possible to recognise podomere homologs. Their differing opinions on homology are mentioned only briefly below in the context of a chronology of Solaenodolichopus. My purpose here is to try to explain the reasoning behind particular generic assignments in the past, not to thoroughly review an enduring and still-unresolved controversy.

Solaenodolichopus was first proposed by Verhoeff (1924) as a subgenus of Antichiropus Attems, 1911. Attems (1911) had described seven new species from Western Australia with gonopod telopodites divided into three main parts: a small, densely setose, basal portion (Femur); a long, cylindrical, slender, central portion (Tibia) tipped with short prongs (Zacken); and a long, thin, coiled, apical portion (Kanalast) carrying the prostatic groove and its terminal opening. Attems assumed that the tarsus of the modified leg had fused with the tibia, and that the distal portion of the tibia was its tarsal section (Tarsalabschnitt). 
In his view, the first joint of this tarsal section consisted of the Kanalast and a prong-like process ' $a$ ' at the end of the tibia and close to the prostatic groove. Attems suggested that another tibial process, 'c', was a remnant of a second tarsal joint. (For a discussion of the Antichiropus gonopod and its components, see Car et al. 2013.)

Verhoeff (1924) described the telopodites of the new central Queensland species teres and the southern Queensland vittatus (the latter divided into two subspecies) as likewise having a small, densely setose, basal portion (Praefemur); a long, cylindrical, slender, central portion (Femur) tipped with short accessory branches (Nebenäste); and a long, terminal process carrying the prostatic groove and its opening. Verhoeff regarded the latter as an evolutionarily novel structure (Neubildung) he called a Solänomerit, which he had recognised in many other Polydesmida and which had no homologue on a walking leg; in what follows I will use the modern term 'solenomere'. The two Queensland species were placed in Antichiropus (Solaenodolichopus) not because this arrangement was definitive (wrote Verhoeff), but because the two species seemed more closely related to those in Antichiropus than to any other species he had previously examined. The gonopod telopodites were fundamentally similar and the first male legs (bearing a short, rounded, ventral, femoral process) were almost identical.

According to Verhoeff (1924), the polydesmidan solenomere was primitively protected by a long tibiotarsus, but there were four secondary developments away from this pattern. In one development (Verhoeff's case 1), the tibiotarsus was reduced so much that the solenomere became the free end of the gonopod, as in Antichiropus. The tibiotarsus had either disappeared completely in Antichiropus, or had been reduced to one of the small accessory branches at the end of the femur (Attems' Zacken). In another development (case 4), the tibiotarsus and solenomere fused into a single process. The two developments could overlap (Verhoeff 1924: 6, "Die Fälle N. 1 und 4 gehen übrigens in einander über"). In the new Queensland species, Verhoeff believed he could detect a fusion in which the solenomere had dominated, so that the tibiotarsus was reduced to a small subterminal tooth on the teres solenomere and a larger but likewise distal process on the solenomere in vittatus.

In the same 1924 paper, Verhoeff proposed Aulacoporus as a new genus for three northern Queensland species. Aulacoporus was distinguished from Antichiropus (Solaenodolichopus) in two ways. First, the prostatic groove opened at the extreme tip of the solenomere in Aulacoporus, whereas in Antichiropus (Solaenodolichopus) the opening was carried on a near-apical process of the solenomere. The solenomere and tibiotarsus had fused in Aulacoporus, but the tibiotarsus had completely disappeared in one Aulacoporus species and in the other two was reduced to a distal bulge on the solenomere.

To explain Verhoeff's second diagnostic difference between Aulacoporus and Antichiropus (Solaenodolichopus), I need to digress briefly.

Polydesmidan species have been classified, in part, on the structure of the paranota, which are lateral extensions of the body wall. In many families the paranota are wide, dorsoventrally flattened and more or less horizontal. In some families there are species with no detectable paranota, at least on diplosegments, i.e. the body rings are simple circles in cross-section. Between these two extremes, paranota are often said to be 'reduced'. Verhoeff (1924) attempted to refine the description of paranota for classification purposes. Instead of Kiel (keel, carina) for paranota in general, Verhoeff proposed Seitenwülste (lateral bulges) for all lateral swellings and extensions. In species with wide, dorsoventrally flattened, wing-like Seitenwülste, the term Seitenflügel (lateral wings) would be appropriate. Each Seitenwulst was often accompanied medially by a narrow, dorsal, longitudinal furrow which Verhoeff called a Seitenfurche (lateral groove). Species with no Seitenwülste at all might or might not have Seitenfurchen. 
Attems (1937) used these terms slightly differently. He observed that well-developed paranota, i.e., Seitenflügel, often had swollen lateral margins. In some species the paranota had narrowed so much that only these marginal thickenings were still present, in which case one could speak of Seitenwülste, and in species without Seitenwülste there might still remain the medial, demarcating grooves, the Seitenfurchen. Both Attems and Verhoeff understood these variations as an evolutionary series in which primitively wide paranota were progressively reduced to bulges and, before disappearing entirely, to short, fine, lateral grooves on the metazonites.

The Aulacoporus and Antichiropus (Solaenodolichopus) species described by Verhoeff had reduced but detectable paranota on the haplosegments, i.e. rings 2-4. Neither group had Seitenwülste on the diplosegments, but there were distinct Seitenfurchen in Aulacoporus and none at all in Antichiropus (Solaenodolichopus).

Attems (1926) accepted both Aulacoporus and Solaenodolichopus (as a subgenus of Antichiropus), but reiterated his view that beyond the coxa on the gonopod were only a femur, tibia and tarsus. Verhoeff's Solänomerit was simply a tibial extension (Tibialfortsatz). In a key to paradoxosomatid genera ('Strongylosomidae'), Attems (1926) separated Aulacoporus (and other genera) having a simple telopodite without side branches or a tarsal section, from Antichiropus (and other genera) having a multitipped telopodite. The key listed Antichiropus as having 1-3 short processes, probably tarsal remnants, near the base of the tibial extension (i.e., the solenomere).

Verhoeff (1928) raised Solaenodolichopus to a genus and added two new species from NSW, rubriventris and walesius. He also proposed Paraulacoporus for another new NSW species, sulcatus. In Paraulacoporus as in Aulacoporus there were short Seitenfurchen on most diplosegments, although the grooves were indistinct on rings 15-19. Unlike Aulacoporus but like Solaenodolichopus, Paraulacoporus was characterised by a prostatic groove opening proximal to the solenomere tip. Unlike the situation in Solaenodolichopus, the two accessory branches at the end of the femur in Paraulacoporus were of equal size, and the process lateral to the prostatic groove opening on the solenomere was forked. Verhoeff described this forked process as a 'tarsal branch'.

Brolemann (1931) assigned a new New Caledonian species, pruvoti, to Paraulacoporus, although he observed no lateral groove (sillon) past ring 5. Combining the ideas of Attems and Verhoeff, Brolemann described the pruvoti telopodite as consisting of a short, densely setose, basal femoroid (fémoroïde), a long, slender tibia and a terminal seminal branch (rameau séminale). He regarded the short, posteromedial process at the end of the tibia as a reduced tarsus separate from the seminal branch, and rejected Verhoeff's opinion that the seminal branch in P. sulcatus was a fusion of solenomere and tibiotarsus. Brolemann also objected to the placement of Solaenodolichopus within Antichiropus by Verhoeff and Attems. He suggested instead that Paraulacoporus and Solaenodolichopus could be grouped together because both had an erect, expanded, more or less divided seminal branch, not a long, coiled strap as in Antichiropus.

Verhoeff (1932) offered simple new keys to the known Australian paradoxosomatids ('Strongylosomidae') based either on trunk details or gonopod structure. In the latter key, Aulacoporus, Paraulacoporus, Solaenodolichopus and Walesoma Verhoeff, 1928 were grouped as genera in which a long solenomere led from the end of the femur, which also might have 1-2 accessory branches at its apex. Aulacoporus and Walesoma were paired as genera in which the opening of the prostatic groove was at the extreme end of the telopodite, with no accessory process either proximal or distal to the opening. Paraulacoporus and Solaenodolichopus were paired as genera in which the opening of the prostatic groove was proximal to the extreme end of the telopodite, with accessory processes both proximal and distal to the opening. 
Attems (1937) revised his nomenclature of sections of the gonopod telopodite, renaming femur, tibia and tarsus as prefemur, femur and tibiotarsus. The process carrying the prostatic groove (Samenrinne) and its opening was the Rinnenast (groove-branch) and was a process of the femur. More importantly, in 1937 Attems synonymised both Paraulacoporus and Solaenodolichopus under Aulacoporus. He described the gonopod and paranota in the expanded genus as follows (Attems 1937: 260-261, my translation): "Gonopod femur long to very long and slender, at the end with one or no side-branch. Rinnenast very large and broad, with one, sometimes two side-teeth. The tibiotarsus is reduced to a small spine. Seitenwülste weakly developed, low, round, sometimes only present on anterior segments. Longitudinal grooves either present on most segments or lacking from segments 5 or 6 onwards". In his key to Aulacoporus species, Attems separated the former Aulacoporus species from the former Paraulacoporus and Solaenodolichopus species simply on the presence or absence of Seitenfurchen on most rings.

Verhoeff (1937) described the new species castaneum from NSW and assigned it to a new genus, Parwalesoma. He noted that Parwalesoma was close to both Aulacoporus and Solaenodolichopus, but differed from the former genus in lacking Seitenfurchen on most rings. Parwalesoma and Solaenodolichopus differed in a somewhat sharper demarcation between femur and solenomere, and in the solenomere tip in P. castaneum being spoon-shaped. Parwalesoma castaneum Verhoeff, 1937 was in fact Solaenodolichopus walesius Verhoeff, 1928 redescribed from new material (see below under $S$. walesius), but it was another 60+ years before Verhoeff's confusion was detected by Jeekel (2000; see below).

In his last contribution to the Solaenodolichopus story, Verhoeff (1941) unwittingly redescribed Brolemann's S. pruvoti (from New Caledonia) as Solaenodolichopus annulatus (from Brisbane). He also offered a key to genera in which he separated the taxa lumped by Attems (1937). The relevant portion of the key is as follows (Verhoeff 1941: 8, my translation with Verhoeff's terminology updated):

c) Solenomere divided at the end into two branches, the medial one extending as three protuberances, of which the middle contains the opening of the prostatic groove, the proximal one a bend in the prostatic groove. Trunk without Seitenwülste but with Seitenfurchen ......Paraulacoporus Verh.

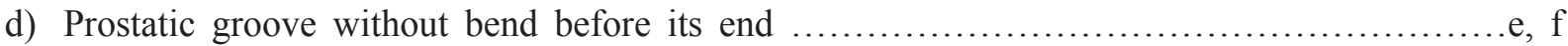

e) Solenomere before its end with a spoon-shaped concavity. Trunk with neither Seitenwülste nor

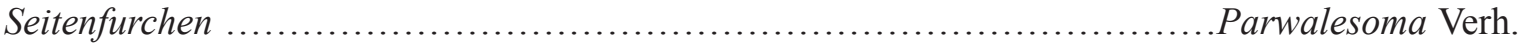

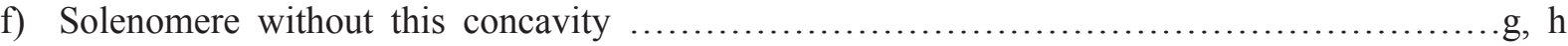

g) End of the solenomere drawn out into two closely standing tips, of which the more proximal contains the opening of the prostatic groove. Trunk with neither Seitenwülste nor Seitenfurchen

....................................................................... Solaenodolichopus Verh.

h) Opening of the prostatic groove in a simple, apical tip............................................

i) Solenomere significantly shorter than femur, its base enlarged, its end hooked. Trunk without Seitenwülste but with Seitenfurchen ...................................Aulacoporus Verh.

j) Solenomere and femur about equally long, the solenomere base not swollen. Trunk with weak, posteriorly rounded Seitenwülste and Seitenfurchen ...........................Walesoma Verh.

Reviewing the Australian Antichiropodini, Jeekel (1968) accepted Attems' (1937) synonymies and Verhoeff's Parwalesoma. Thirty-two years later, he confessed that he regarded Parwalesoma as another Aulacoporus synonym, but had not published this synonymy because the Parwalesoma type species, P. castaneum Verhoeff, 1937, would have become a junior homonym of the Aulacoporus type species, A. castaneus Verhoeff, 1924. "As the broad concept of Aulacoporus was intended to be a temporary 
solution anyway, the introduction of a new name for the type-species of Parwalesoma seemed just too radical" (Jeekel 2000: 40).

Jeekel (2000) then reinstated Solaenodolichopus, leaving within it S. teres, S. vittatus and S. vittatus dorsalis and transferring to it the Paraulacoporus species P. sulcatus and P. pruvoti. He also recognised $S$. annulatus as a synonym of pruvoti. Solaenodolichopus now included species with and without Seitenfurchen, and with considerable variation in the size and position of the processes at the end of the telopodite femur. "The species of this genus are characterised by the solenomerite of the gonopods having a pre-apical latero-distal process paralleling the apex proper. This process distinguishes the genus from the others" (Jeekel 2000: 41).

One of those other genera was Aulacoporus and its three original species, which Jeekel (2000) regarded as distinct not because the solenomere was simple with the prostatic groove opening at its tip, but because the gonopod apex curved strongly cephalad and bore a large lobe laterally - a lobe which Jeekel presumed was the tibiotarsus.

The other genus Jeekel (2000) distinguished from Solaenodolichopus was Parwalesoma. He recognised the type species $P$. castaneum as a junior subjective synonym of $S$. walesius, thus establishing $P$. walesium (Verhoeff, 1928). He also transferred S. rubriventris to Parwalesoma, noting that "In this genus the gonopods are lacking a pre-apical process on the solenomerite, but otherwise are quite similar to those of Solaenodolichopus" (Jeekel 2000: 42).

Jeekel's distinction between Parwalesoma and Solaenodolichopus is questionable in the case of $S$. walesius (see the taxonomic notes following the $S$. walesius redescription, below), and for that reason I am making Parwalesoma a junior subjective synonym of Solaenodolichopus. This action broadens the circumscription of Solaenodolichopus and might allow it to be subsumed under Aulacoporus, as favoured by Attems (1937). However, after examining late 20th-century specimens of Aulacoporus castaneus Verhoeff, 1924, A. yarrabahnus Verhoeff, 1924 and three undescribed Aulacoporus spp., all from a small area in the Queensland Wet Tropics, I agree with Jeekel (2000) that this genus is best kept separate from Solaenodolichopus. All Aulacoporus forms have prominent lateral grooves and slight paranotal swellings on all diplosegments, and in four of the six Aulacoporus forms the solenomere curves anteriorly. None of the Solaenodolichopus I have examined (as diagnosed above) has either prominent lateral grooves on all diplosegments or an anteriorly curving solenomere.

\section{Diagnosis}

Australian Paradoxosomatidae without distinct paranota on posterior rings, and with a gonopod telopodite with a small, densely setose prefemur and a more or less straight, slender and cylindrical femorite ending in an unbranched medial process, an unbranched lateral process and a much larger solenomere with a flattened tip on which the prostatic groove usually opens medially.

\section{Description}

Male with vertex bare, frons and clypeus sparsely setose; vertigial sulcus distinct, ending anteriorly just above level of antennal sockets; post-antennal groove shallow; antennal sockets separated by $1.0-1.1 \mathrm{X}$ a socket diameter. Antenna filiform (Fig. 1A), reaching dorsally to rear of ring 2; antennomere with relative lengths typically $(2,3,4)>(5,6)$, the differences small, and maximum distal widths subequal or with 6 very slightly wider. Head and collum about equal in width in dorsal view, about as wide as rings 2-4 or a little narrower; diplosegments a little wider, slightly increasing in width to midbody, width decreasing progressively on last rings. Collum D-shaped in dorsal view; anterior margin straight medially, gently curving laterally; posterior margin straight or very slightly emarginate medially; collum corner broadly rounded (Fig. 1A). Ring 2 paranotum (Fig. 1A) a slightly thickened, overhanging ridge, 
nearly straight and more or less longitudinal, corners rounded, set at $c a$. 1/4 ring height or a little less, below level of collum corner. Rings 3 and 4 paranota (Fig. 1A) at about level of collum corner, reduced to shallow furrows curving upwards anteriorly. Pleural keels present on rings 2-4 as slight thickenings with upwardly curving margins. Diplosegments without paranotal thickenings, rings circular in crosssection. Prozonites and metazonites smooth, bare; waist short, shallow, with suture at anterior edge, sculptured indistinctly as variably low, rounded, longitudinal ridges; limbus a short, thin, continuous sheet. Pore formula normal; ozopores small, round, flush with lateral surface of ring, set at mid-height
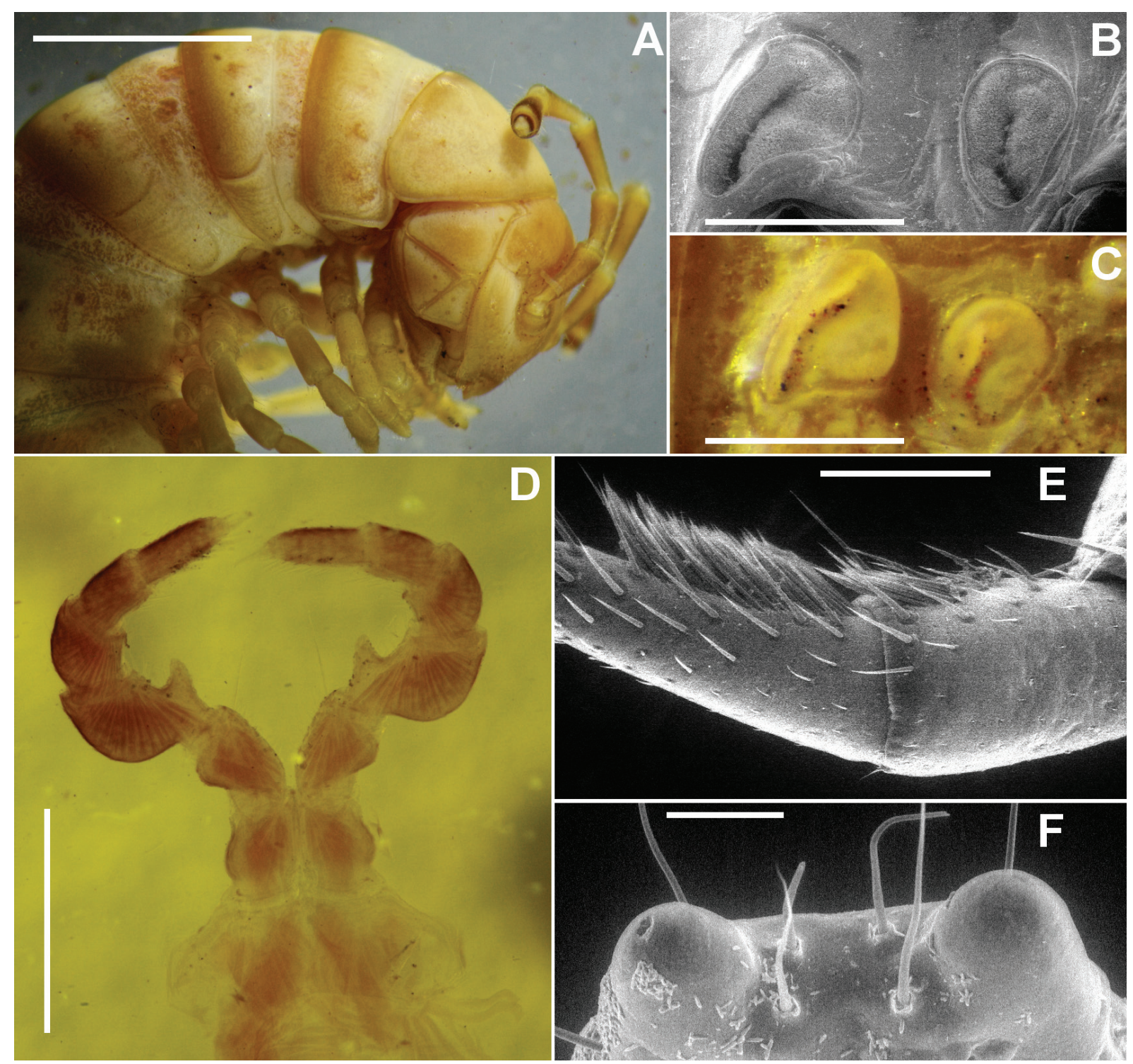

Fig. 1. - A-B. Solaenodolichopus walesius Verhoeff, 1928. A. Lectotype $\widehat{\jmath}$, AM KS.76508, right anterior view. B. $\widehat{\sigma}$ ex AM KS.16152, midbody spiracles, ventral view, anterior to left. - C, E. $S$. vittatus (Verhoeff, 1924). C. Paralectotype 9 , NHRS KAS1000000007, midbody spiracles, ventral view, anterior to left (image right-left reversed for ease of comparison with 1B). E. $\sigma^{\widehat{T}}$ ex QM S74828, anterior leg tip with scopula, tarsus at left. - D. S. teres (Verhoeff, 1924), lectotype ô slide mount, NHRS KAS1000000005, legpair 1. - F. S. pruvoti (Brolemann, 1931), ठ̂ ex QM S74856, epiproct, posterior and slightly ventral view. Scale bars: $A=2.5 \mathrm{~mm}, \mathrm{~B}-\mathrm{C}=0.5 \mathrm{~mm}, \mathrm{D}=1 \mathrm{~mm}, \mathrm{E}=0.25 \mathrm{~mm}, \mathrm{~F}$ $=0.1 \mathrm{~mm}$. 
and mid-length on metazonite, in line with transverse furrow (when present). Diplosegment spiracles (Fig. 1B-C) just above and anterior to leg bases, more or less egg-shaped with smaller end ventral, anterior spiracle larger and extended anteroventrally; spiracles with thin, short rim; spiracular filter slightly emergent, forming rounded fold in inverted, tight U-shape in spiracular opening (Fig. 1B-C). Midbody sternites about as long as wide, sparsely setose; cross impressions wide, shallow, transverse impressions a little narrower and deeper than longitudinal. Leg 1 (Fig. 1D) with small, bluntly rounded, ventral, femoral process curving slightly distally, reaching to $c a$. 1/2 length of femur on ventral side. Midbody legs with relative podomere lengths femur $>$ prefemur $>$ (postfemur, tibia, tarsus) or tarsus very slightly longer than postfemur and tibia; femur $1.7-1.8 \mathrm{X}$ as long as tarsus; prefemora a little swollen dorsally. Dense brush (scopula) (Fig. 1E) of straight, finely pointed setae ventrally on tarsus and distal portion of tibia of most legs. Epiproct extending a little past anal valves, tapering in dorsal view with sides more or less straight, $c a$. 1/4-1/3 maximum width of preanal ring at apex; apex truncate, corners produced posteriorly as small, rounded bumps (Fig. 1F); spinnerets in rectangular array, wider than long. Hypoproct subtrapezoidal to broadly paraboloid. Gonopore small, round, opening ventrally on slight distomedial swelling of leg 2 coxa. Sternal lamella (Fig. 2) wide, ca. 80-90\% of width between leg 4 bases, perpendicular to ring or slightly tilted anteriorly, with sparse long setae on posterior surface and dense, short setae on anterodistal surface. Aperture $c a$. 1/3 of ring 7 prozonite width, roundedrectangular and tilted slightly posteriorly; prominent, rounded, transverse swelling just anterolateral to aperture on either side (Fig. 3A).

Female very similar to male but with legs proportionally shorter, prefemora not swollen; epigyne $c a$. 1/6-1/5 ring width, ends slightly raised and cradling leg 2 coxae, centre slightly raised in small, rounded triangle (Fig. 3C).
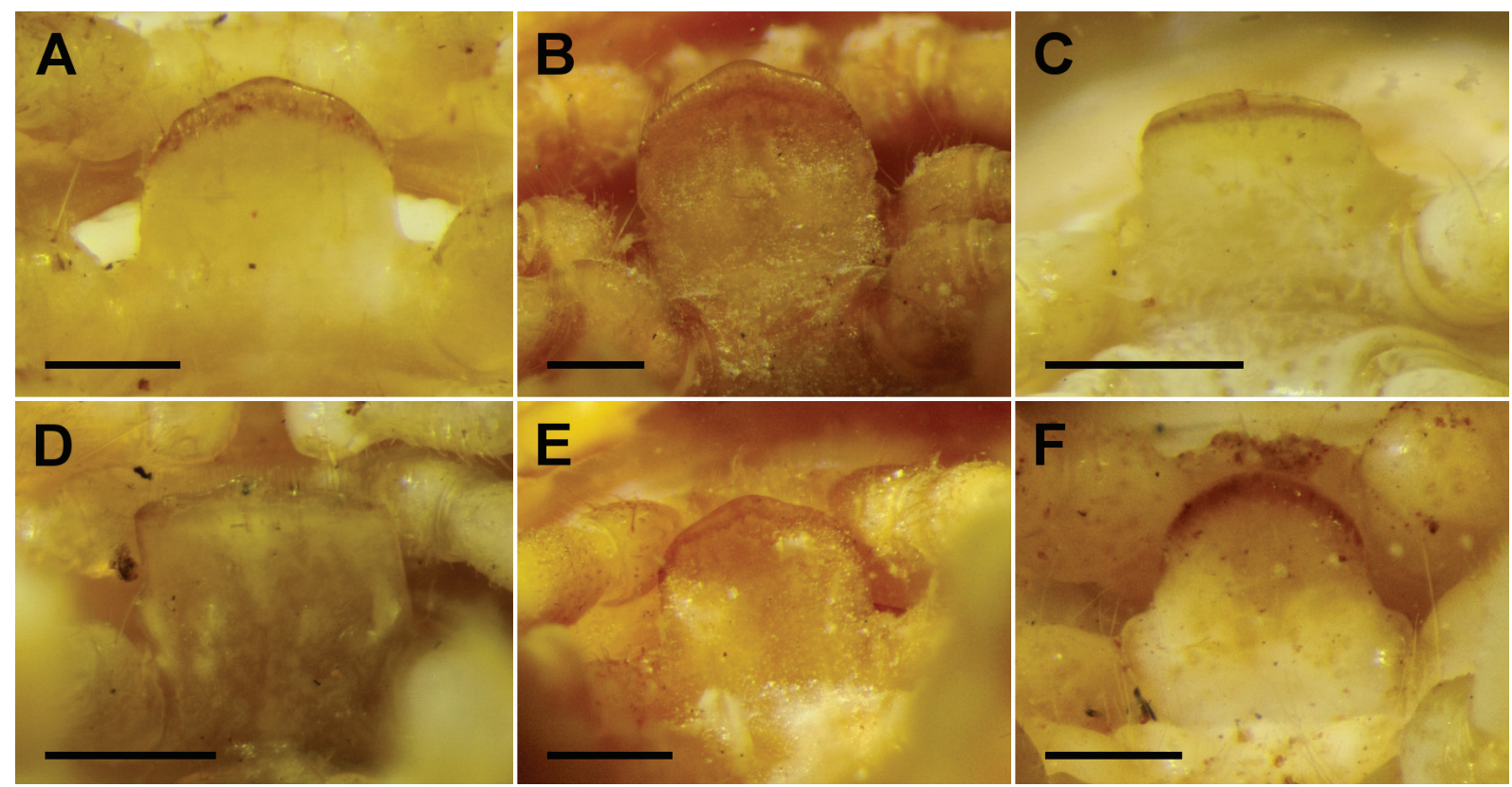

Fig. 2. Posterior views of sternal lamella in $\widehat{\partial} \widehat{\partial}$. - A. Solaenodolichopus pruvoti (Brolemann, 1931), QM S74856. - B. S. rubriventris Verhoeff, 1928, QM S74690. - C. S. sulcatus (Verhoeff, 1928), lectotype, AM KS.76503. - D. S. teres (Verhoeff, 1924), lectotype in alcohol, ZSM A20052188. — E. S. vittatus (Verhoeff, 1924), QM S74829. - F. S. walesius Verhoeff, 1928, lectotype, AM KS.76508. Scale bars: $0.5 \mathrm{~mm}$. 


\section{Species-diagnostic characters}

Adults of the six named Solaenodolichopus species conform to the genus description above. Omitted from the genus description are diagnostic characters reported in the descriptions of individual species, below. Besides gonopod structure, these species-diagnostic characters are: colour, maximum midbody width, transverse furrow distinctness, longitudinal furrow details for diplosegments, distribution of scopulae on legs, sternal lamella details, leg spacing on rings 6 and 8, shape of the anterior margin of the gonopod aperture, and leg 2 coxa details in females.

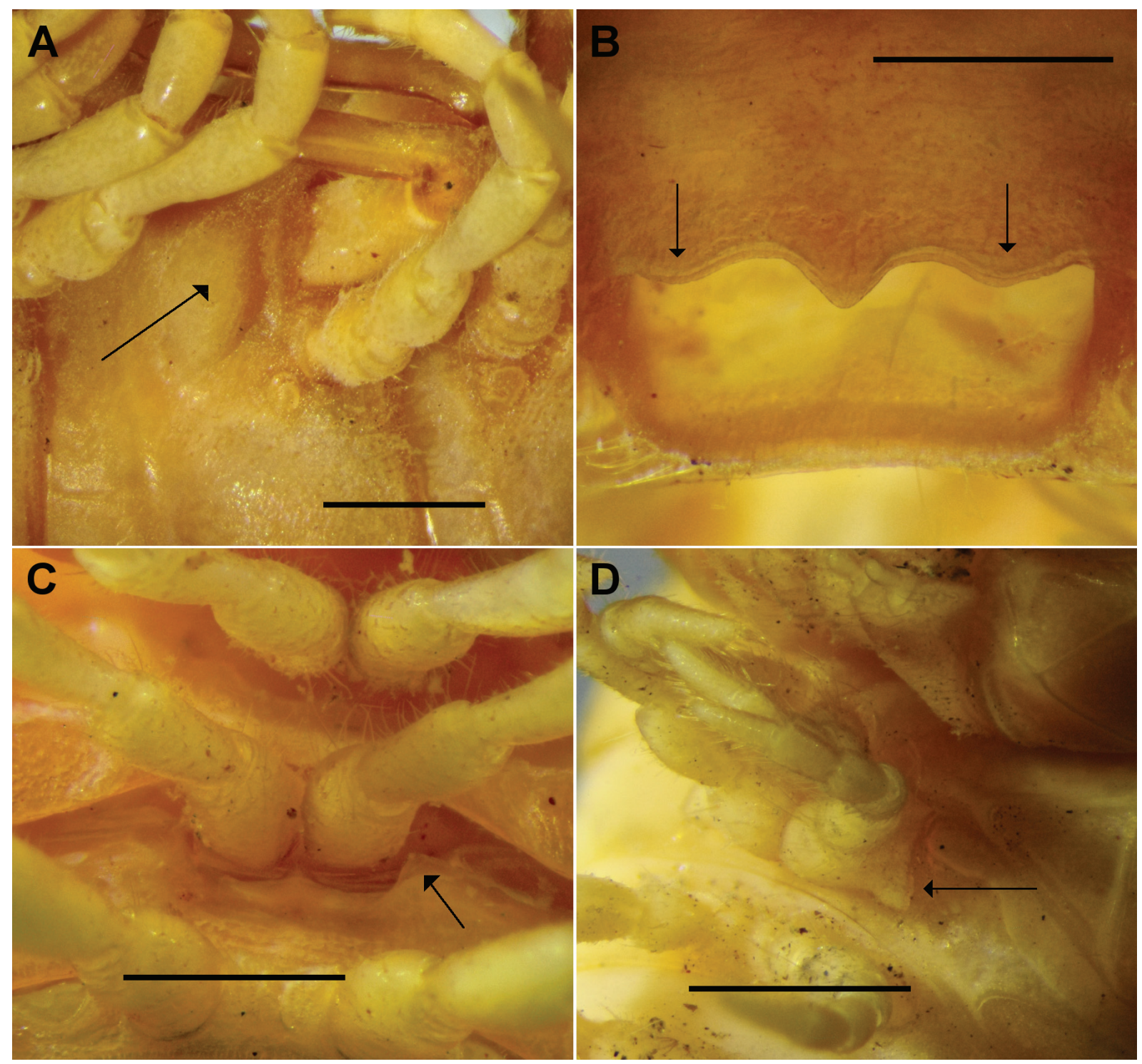

Fig. 3. - A-B. Solaenodolichopus rubriventris Verhoeff, 1928, ô, QM S74690. A. Right ventrolateral view of ring 7 showing swelling (arrow) just anterolateral to aperture. B. Ventral view of aperture showing gently convex extensions (arrows) on either side of medial extension on anterior margin of aperture. - C. S. walesius Verhoeff, 1928, ㅇ, AM KS.16152, posteroventral view of epigyne showing raised end (arrow). - D. S. teres (Verhoeff, 1924), paralectotype ${ }_{+}$, NHRS KAS1000000007, left ventrolateral view of anterior rings showing distolateral process on leg 2 coxa (arrow) just medial to raised end of epigyne. Scale bars: $1 \mathrm{~mm}$. 
In the species descriptions I use the terms 'prefemur', 'femorite' and 'solenomere' in agreement with the usage of Car et al. (2013: 84) for Antichiropus; the terms are not intended to be implied statements of homology.

A brief dichotomous key to the six named Solaenodolichopus species follows. The key will need major revision as the many undescribed species are named and documented in future papers in this series.

1. Body pale yellow or light brown with narrow dark brown rings at the rear of each metazonite S. pruvoti (Brolemann, 1931)

- Body more or less uniformly dark in colour, with or without a lighter, medial dorsal, longitudinal band

2. Longitudinal furrows laterally at level of ozopore on diplosegments to about ring 15, medial and lateral femorite processes obvious, spine-like, about equal in length ......S. sulcatus (Verhoeff, 1928)

- No longitudinal furrows laterally on any diplosegment, medial and lateral femorite processes

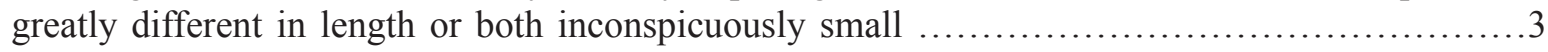

3. Lateral femorite process much larger than medial .................S. walesius Verhoeff, 1928

- Medial femorite process much larger than lateral, or both femorite processes inconspicuously small

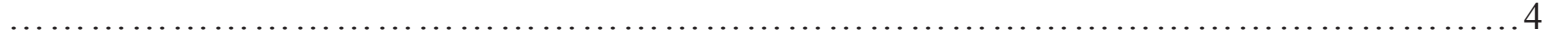

4. Distal $1 / 3$ of femorite bent at $c a .45^{\circ}$, femorite processes inconspicuously small

S. teres (Verhoeff, 1924)

- Femorite straight, medial femorite process large and obvious

5. Solenomere with several spine-like processes in basal half, no large indentation in distal half ..S. rubriventris Verhoeff, 1928

- Solenomere without spine-like process in basal half, with large, U-shaped indentation in distal half

S. vittatus (Verhoeff, 1924)

Solaenodolichopus pruvoti (Brolemann, 1931)

Figs 1F, 2A, 4A-B, 5, 6A-B, 7, 10A, 11D

Paraulacoporus Pruvoti Brolemann, 1931: 295 (first description); figs 29-32 (p. 297), 33-35 (p. 299).

Solänodolichopus annulatus Verhoeff, 1941: 11 (first description); figs 1-4 (p. 23).

Solaenodolichopus pruvoti - Jeekel 2000: 40 (new combination), 42, 46. - Nguyen \& Sierwald 2013: 1159.

Solaenodolichopus annulatus - Jeekel 2002: 60 (as synonym of Solaenodolichopus pruvoti).

Solänodolichopus annulatus - Nguyen \& Sierwald 2013: 1159 (as synonym of Solaenodolichopus pruvoti).

Aulacoporus pruvoti - Attems 1937: 261 (new combination), 264 (Brolemann's 1931 description reworded); fig. 331 (p. 265; same as fig. 32 in Brolemann 1931). — Jeekel 1968: 18, 29; 1981: 47; 1985: 34.

Aulacoporus annulatus - Jeekel 1968: 20, 29; 1981: 49; 2000: 41 (synonymised with Solaenodolichopus pruvoti), 42 .

non? Solaenodolichopus pruvoti - Jeekel 2002: 60 (partial redescription from new material), 77; fig. 1 (p. 62).

non? Aulacoporus pruvoti - Jeekel 1982: 124 (redescription from new material); figs 2, 3 (p. 126). 


\section{Material examined}

\section{Syntypes of $S$. pruvoti}

At least 1 male and 1 female, Dumbéa, New Caledonia [2209' S, $166^{\circ} 27^{\prime}$ E, \pm 5 km], date unknown, A. Pruvot-Fol; specimens not located.

\section{Syntypes of $S$. annulatus}

At least 1 male, Brisbane, QLD [27²8’ S, $\left.153^{\circ} 01^{\prime} \mathrm{E}, \pm 10 \mathrm{~km}\right]$, Dec. 1936, J. Mauritzon; specimens not located.

\section{Other material}

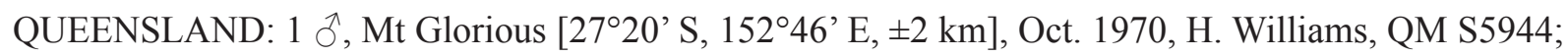

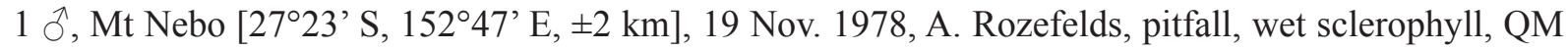

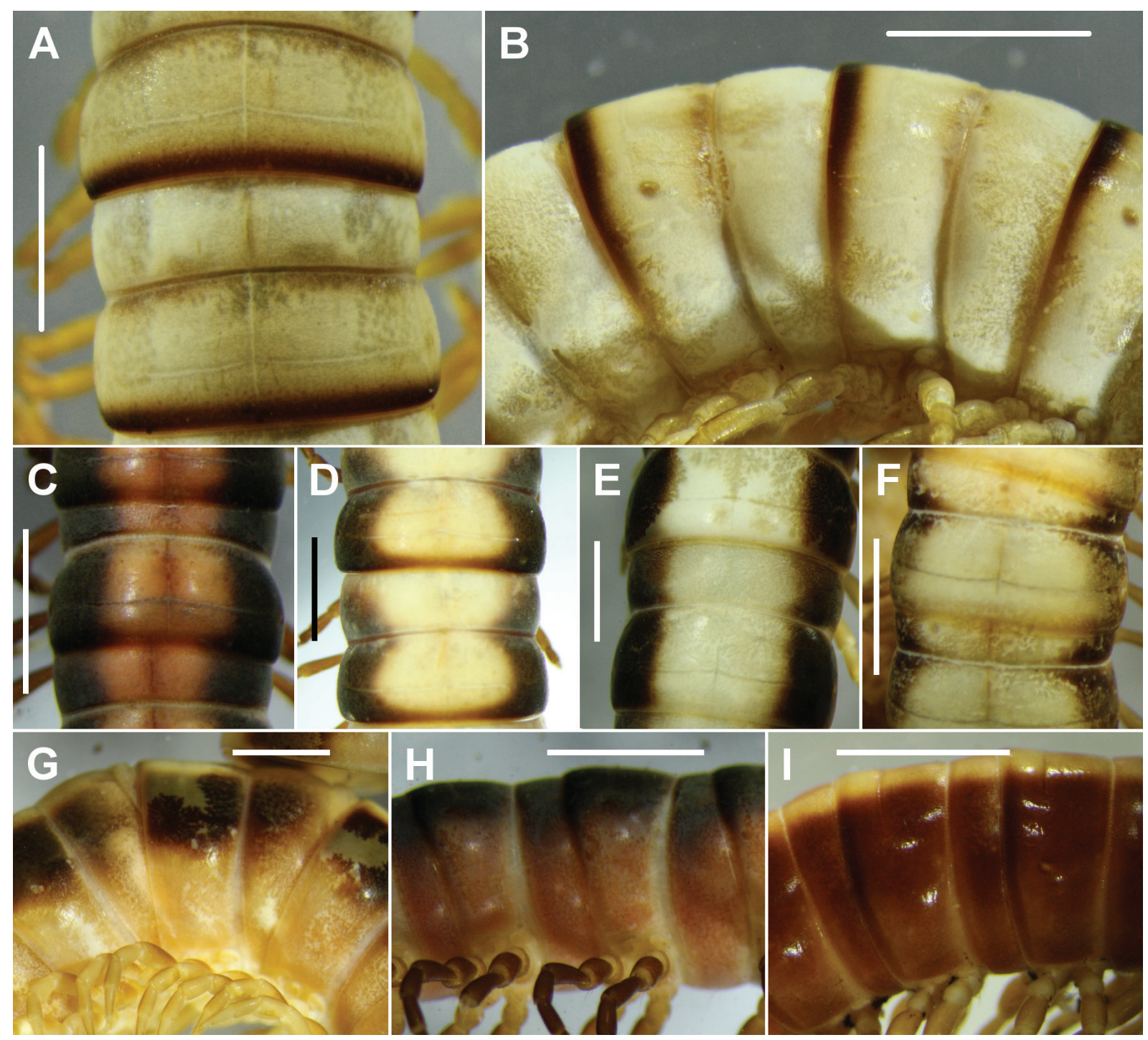

Fig. 4. - A-B. Solaenodolichopus pruvoti (Brolemann, 1931), QM S74856. Dorsal (A) and lateral (B)

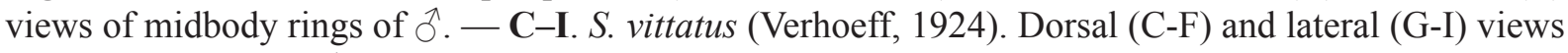
of midbody rings of ${ }^{7}$; QM S74767 (C, H), QM S74855 (D), QM S74836 (E, G), QM S74876 (F), QM S5946 (I). Scale bars: $2 \mathrm{~mm}$. 


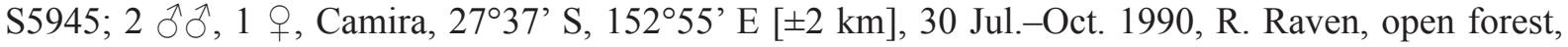

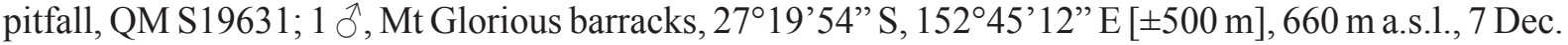
1991-6 Mar. 1992, G. Monteith, rainforest, pitfall+intercept, QM S74833; 1 ð, Mt Mee, 2702’53" S, $152^{\circ} 40^{\prime} 49 ”$ E [ $\left.\pm 500 \mathrm{~m}\right], 300 \mathrm{~m}$ a.s.l., 3 Mar.-12 Apr. 1992, D. Cook, rainforest, intercept, QM S74834;

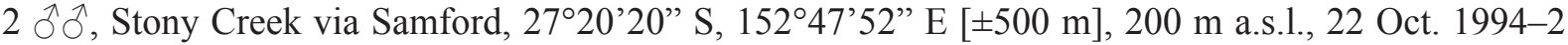
Feb. 1995, H. Janetzki and G. Monteith, rainforest, pitfall, QM S74835; 1 त, 1 +, Camerons Scrub, knoll top, 27³0'27' S, 15243'40" E [ \pm 500 m], 90 m a.s.1., 15 Sep.-11 Nov. 1998, G. Monteith, D. Cook and G. Thompson, vine scrub, pitfall, sample 7380, QM S74841; 3 $\lesssim$, 1 ㅇ, same details but 11 Nov. 1998-13 Jan. 1999, sample 7557, QM S74856; 1 đ, same details but Camerons Scrub, top ridge,
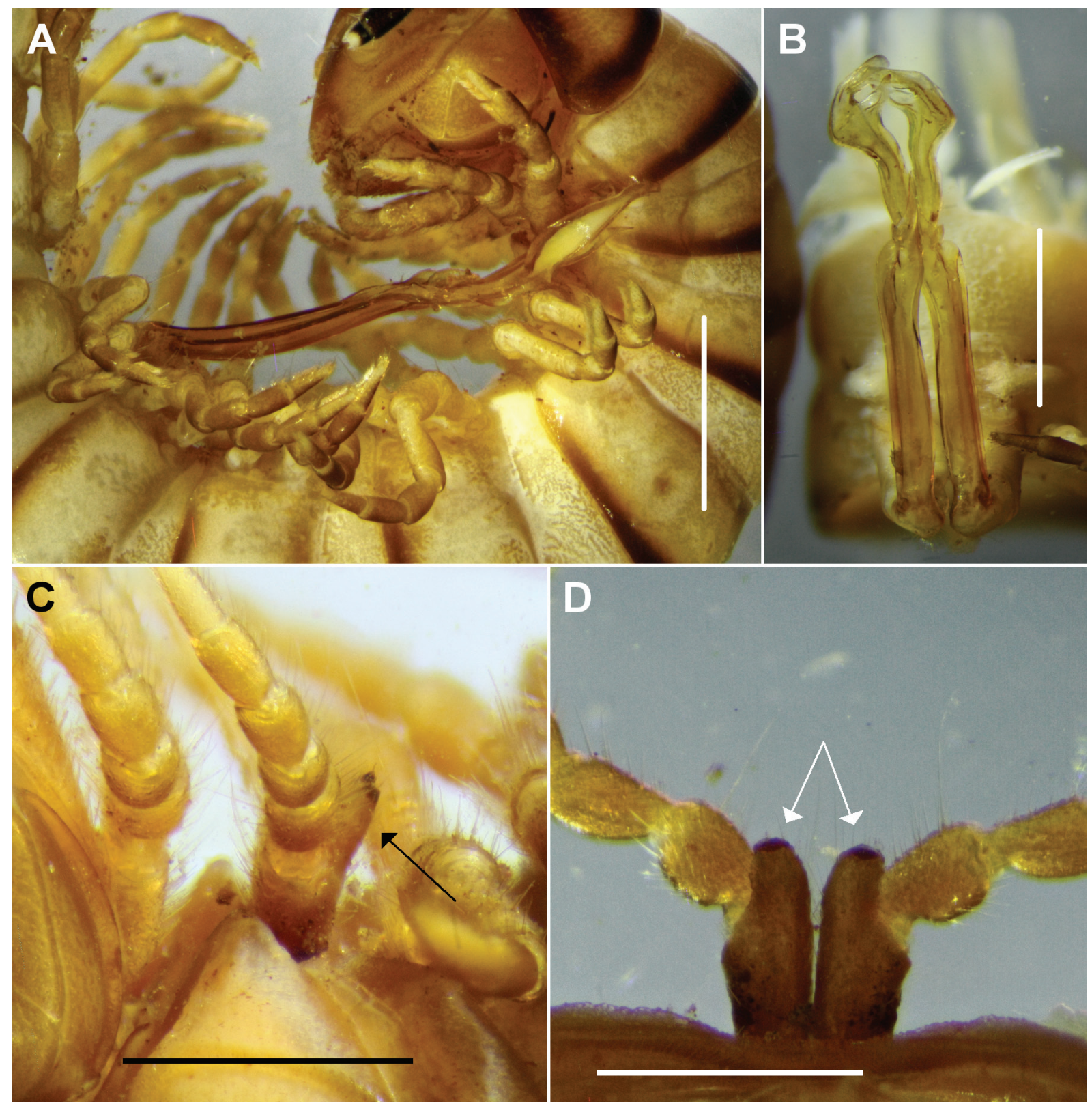

Fig. 5. Solaenodolichopus pruvoti (Brolemann, 1931). A. Anterior lateral view showing reach of gonopod telopodites, QM S74856. B. Posterior view of gonopods, WAM T52345. C-D. Lateral (C) and posterior (D) views of leg 2 coxal process in + , QM S74857. Scale bars: A-B $=2 \mathrm{~mm}, \mathrm{C}-\mathrm{D}=1 \mathrm{~mm}$. 
27³0'29” S, 152 43'54” E [ \pm 500 m], 160 m a.s.1., 21 Sep.-11 Nov. 1998, sample 7381, QM S74842; 1 ऽ, 1 q, same details but 13 Jan.-16 May 1999, sample 7666, QM S74864; 1 ô, 1 क, same details but Camerons Scrub, below road, 27³0’45” S, 152 43’39” E [ \pm 500 m], 40 m a.s.l., 11 Nov. 1998-13 Jan.

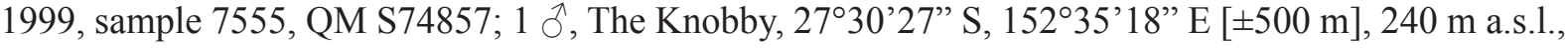
11 Nov. 1998-13 Jan. 1999, G. Monteith, D. Cook and G. Thompson, vine scrub, pitfall, sample 7567,

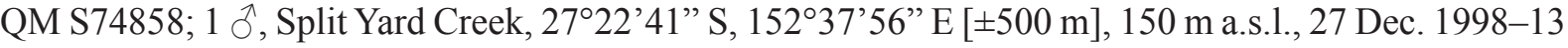
Jan. 1999, G. Monteith, D. Cook and G. Thompson, vine scrub, dung trap, sample 7568, QM S74859; 1

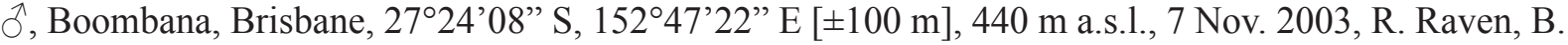
Baehr and O. Seeman, day hand collection, ex S.C. 51695, QM S74874.

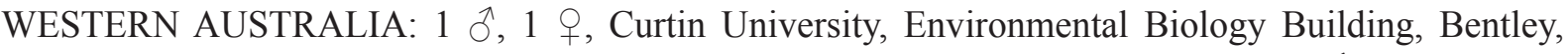
[3200’21” S, 11553'40” E, \pm 200 m], 25 Apr. 2002, T. Cocket, WAM T47890; 1 o, same details

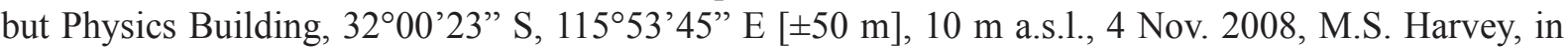

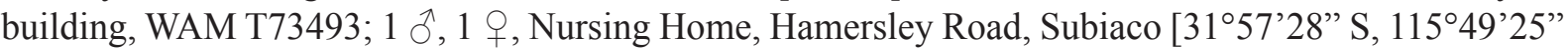
E, \pm 100 m], 30 m a.s.1., 22 Jan. 2003, K. Debnam, inside nursing home, WAM T47891; 1 q, 7 Kingston Street, Nedlands, 31 ${ }^{\circ} 57^{\prime} 56^{\prime \prime}$ S, 11548’46” E [ \pm 100 m], 10 m a.s.l., 19 Apr. 2003, J.M. Waldock, found dead on front verge near driveway, WAM T52005; 1 o, same details but 21 Apr. 2003, J.M. Waldock, walking on footpath in front garden, WAM T52006; 1 o, same details but 19 May 2003, S. Slack-Smith, in garden, WAM T52345; 1 $\hat{\text { }}$, same details but 28 Sep. 2007, WAM T95077; 2 + $ᄋ$, same details but 6-9 Nov. 2008, WAM T94065; 2 ठิ $\widehat{\text {, }} 1$ juvenile, same details but 6 Nov. 2008, on path in garden after rain, WAM T94986; 2 우, 3 juveniles, same details but 8 Dec. 2008, on path in garden, WAM T94973;

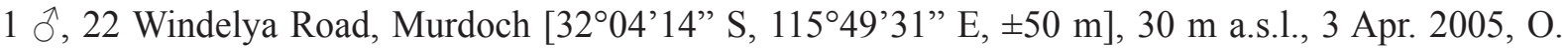

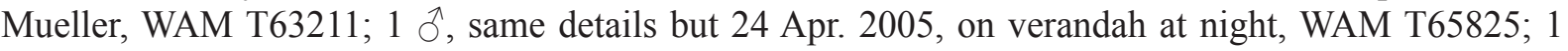
ㅇ, Edward Street, Nedlands, $31^{\circ} 58^{\prime} \mathrm{S}, 115^{\circ} 48^{\prime} \mathrm{E}$ [ $\pm 2 \mathrm{~km}$ ], $20 \mathrm{~m}$ a.s.1., 1 Mar. 2006, A. Baynes, WAM

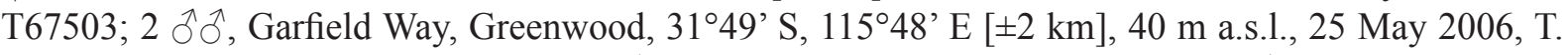

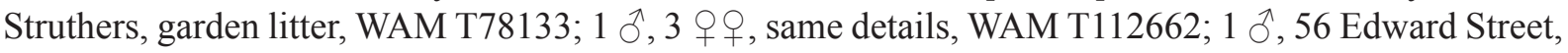

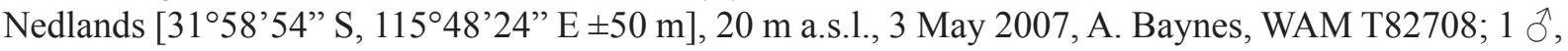
University of Western Australia, Crawley, bus stop on Fairway near corner of Cooper Street, $31^{\circ} 58^{\prime} 41^{\prime \prime}$ S, $115^{\circ} 48^{\prime} 56^{\prime}$ E E $[ \pm 100 \mathrm{~m}], 11$ Jun. 2008, J. Wojcieszek, WAM T89288; 1 đ, 7 Dunkeld Street, Floreat, $31^{\circ} 55^{\prime} 51^{\prime}$ S, $115^{\circ} 47^{\prime} 24 ”$ E [ \pm 100 m], 13 Dec. 2012, J. Foss, WAM T129488.

\section{Description}

(Based mainly on Camerons Scrub, QLD specimens.) As for the genus. Maximum male/female midbody width $c a .3 .8 / 4.4 \mathrm{~mm}$. Colour in alcohol: "Colour brown-black, ringed tawny-pink on the anterior (nested) end of the prozonites and on the median portion of the metazonites. Anal valves black. Legs pale yellow" (Brolemann 1931: 295, my translation); "Bright gray-yellowish with brown posterior margin rings on diplosegments, head mainly dark brown" (Verhoeff 1941, p. 11, my translation); base colour in QLD and WA specimens varying from pale yellow to light brown, with narrow, dark brown ring at rear of haplosegments, diplosegments and apodous ring; darker specimens with very narrow, light brown rings bordering waist; narrow marginal ring of dark brown on collum, brown patches on vertex and clypeus of head and on anal valves, antennomeres brown (darker distally), legs yellowish (Fig. 4A-B).

Male with transverse furrows very shallow, narrow, sometimes indistinct and easily overlooked ("Pas de sillon tranverse sur les métazonites", Brolemann 1931: 296; "Querfurchen sehr fein", Verhoeff 1941: 10). No longitudinal furrows laterally on diplosegments (Fig. 4B). Sternal lamella (Fig. 2A) with sides more or less straight, corners broadly rounded, distal margin convex. Scopulae on legs 1 to 29, i.e. not present on last podous ring. Leg bases on rings 6 and 8 separated more widely than on other rings, sternites a little depressed. Anterior margin of aperture with rounded-triangular, medial extension and shorter, gently convex extension on either side (as shown in Fig. 3B for S. rubriventris). 
Gonocoxa $c a$. 1/2 telopodite length, slightly flattened anteroposteriorly and slightly concave anteriorly, with sparse, long setae anterodistally. Cannula short, narrow, uniformly tapering towards prefemur. Gonopod telopodite (Figs 5A-B, 6A-B, 7, 10A) reaching leg 4 bases on uncoiled specimens. Prefemur small, rounded, densely setose posteromedially, demarcated from femorite laterally by small, narrow notch. Remainder of telopodite clearly divided into femorite and solenomere at $c a$. 1/2 telopodite length. Femorite slender, straight in posterior view, slightly convex anteriorly in lateral view, the posterior surface very slightly concave; tipped with knob-like, rounded shoulder just lateral to lateral femorite process, a short, wide, longitudinal groove running basally from shoulder. Lateral femorite process a short, rounded tab directed anterodistally, close to solenomere base, extending distally a little past femorite shoulder. Medial femorite process teardrop-shaped, the rounded base with thin, translucent cuticle, the point directed anterodistally, terminating close to solenomere at 1/4-1/3 solenomere length. Solenomere at base $c a$. 2/3 femorite width, expanded and anteroposteriorly flattened distally; a narrow, ridge-like flange (arrow in Fig. 7D) along whole of anterior surface of solenomere, diverting medially in short loop at $c a$. $1 / 2$ solenomere length, curving sharply laterally at base to form small, rounded, anterior extension. Solenomere divided at $c a$. 2/3 length by large, U-shaped indentation into medially directed apex and distomedially directed, rounded process terminating just basal to solenomere apex; apex divided by narrow indentation into anteroposteriorly flattened, medially directed, truncate, subapical tab carrying opening of prostatic groove, and apical, basodistally flattened tab extending medially just past
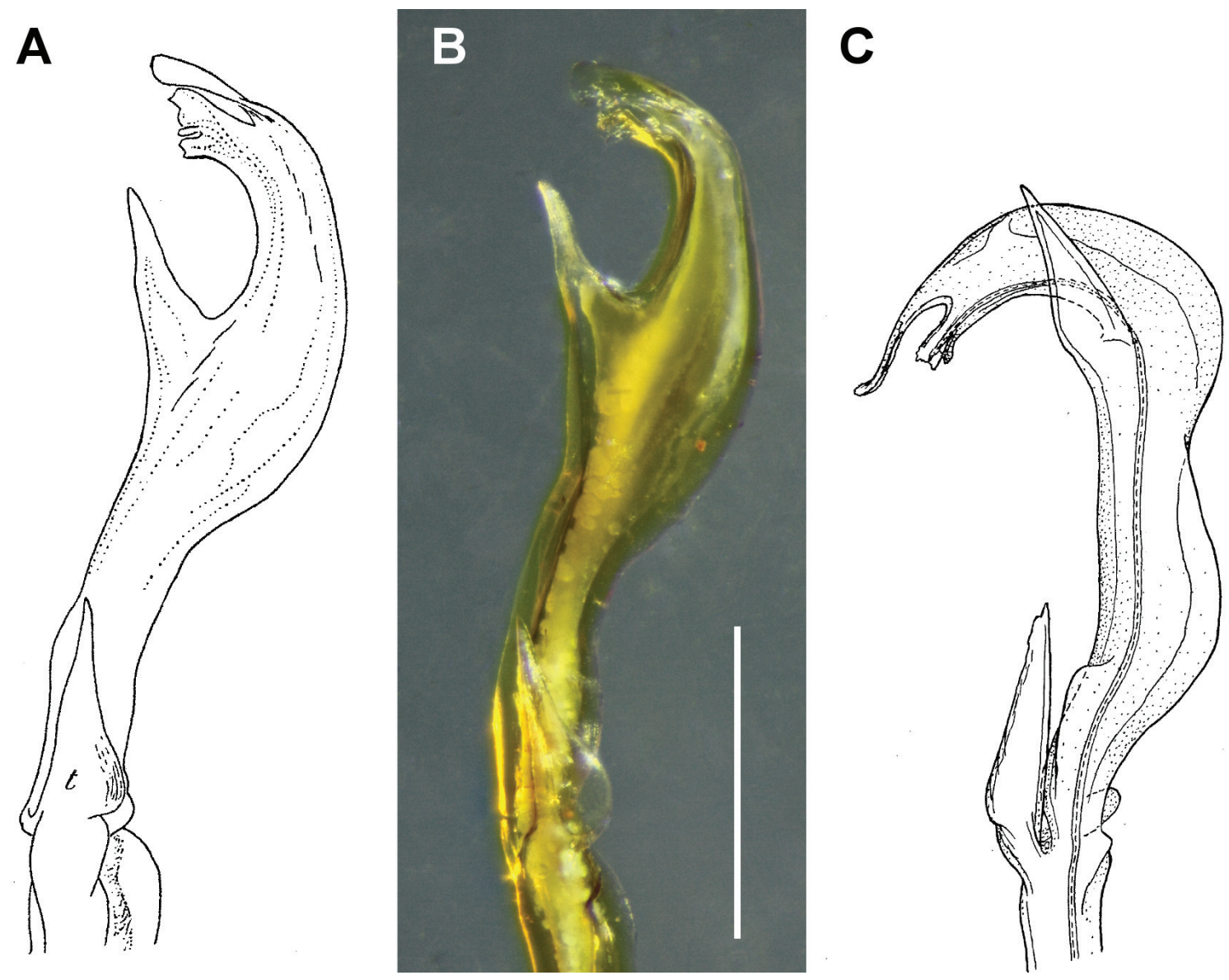

Fig. 6. A-B. Solaenodolichopus pruvoti (Brolemann, 1931); left gonopod solenomere, posterior views. A. Syntype, from fig. 32 in Brolemann (1931). B. QM S74841. - C. Solaenodolichopus ?pruvoti; left gonopod solenomere, posterolateral view, from fig. 3 in Jeekel (1982). Scale bar: $1 \mathrm{~mm}$. 
subapical tab. Prostatic groove (Fig. 7D) running on anterior surface of telopodite, following curve of solenomere medial to flange, terminating at midpoint on medial margin of subapical tab.

Female with leg 2 coxa extended posteroventrally as apically rounded process (Fig. 5C-D).

\section{Distribution}

Known from open forest, rainforest and vine scrub to at least $660 \mathrm{~m}$ a.s.l. in the D'Aguilar Range and adjoining areas west of Brisbane in southeast Queensland, from Mt Mee south to Ipswich, a northsouth extent of $c a .65 \mathrm{~km}$ (map Fig. 12). This is almost certainly the native range of the species, as very similar, undescribed species are found elsewhere in southeast Queensland. Introduced and established in the Perth metropolitan area in Western Australia; so far reported from Kingsley south to Kardinya, a north-south extent of $c a .30 \mathrm{~km}$. Introduced (and established?) in New Caledonia. Overlaps in range with $S$. vittatus.

\section{Taxonomic notes}

The types of $P$. pruvoti and $S$. annulatus have not yet been located, and I prefer not to designate lectotypes for these species based only on the published descriptions and illustrations of Brolemann (1931) and Verhoeff (1941). The Brisbane and Perth specimens listed above agree closely with those descriptions and illustrations (Figs 6A-B, 7A-B).

I suspect that the South Australian specimens described by Jeekel $(1982,2002)$ are an unnamed Solaenodolichopus species, not S. pruvoti. They differ from S. pruvoti in lacking pleural keels and in having a distinct transverse furrow on the metazonites (Jeekel 1982: 125) and a medial coxal process
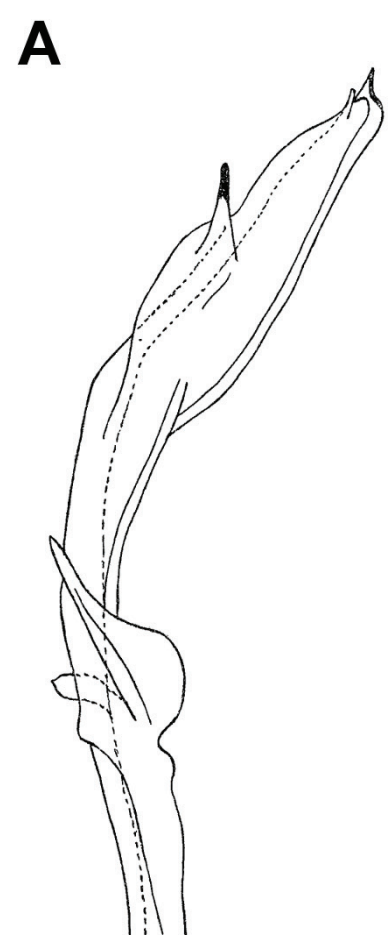
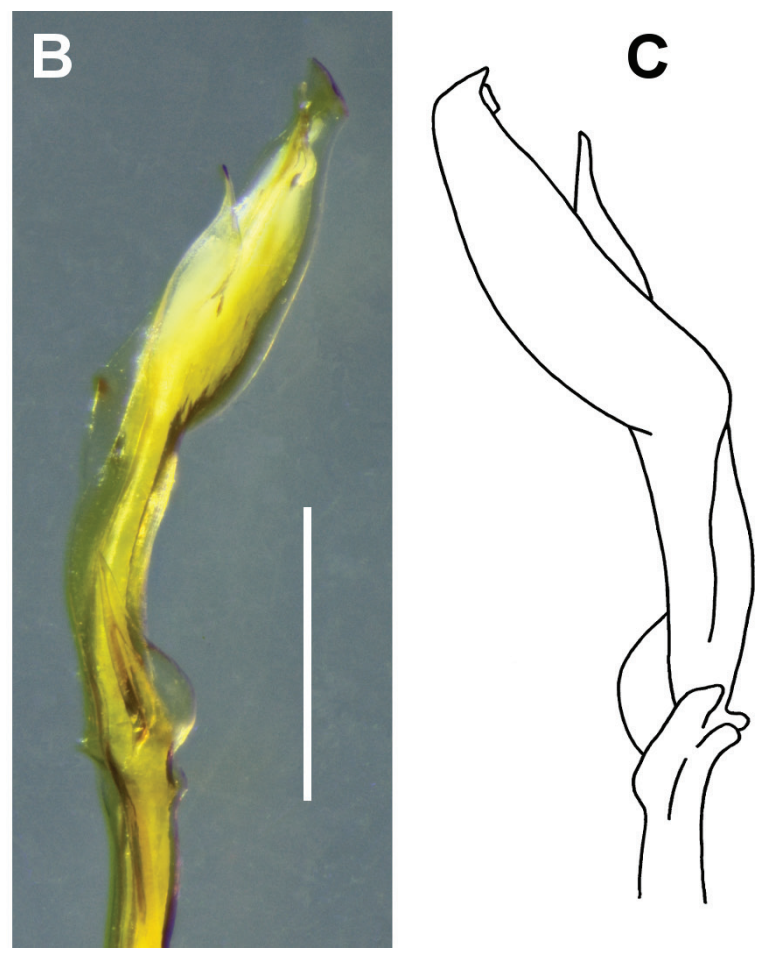

D

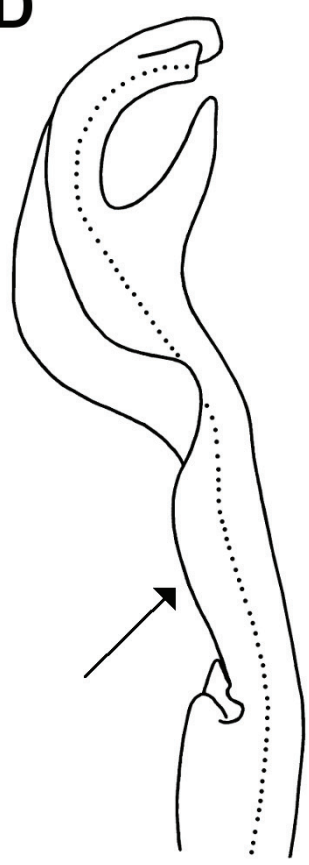

Fig. 7. Solaenodolichopus pruvoti (Brolemann, 1931), left gonopod solenomere. - A-B. Medial views, S. annulatus (= S. pruvoti) syntype from fig. 2 in Verhoeff (1941) (A) and QM S74856 (B). - C-D. Lateral (C) and anterior (D) views, QM S74857. In D, arrow points to flange on anterior surface and dotted line marks course of prostatic groove. Scale bar: $1 \mathrm{~mm}$. 
on male legs 6 and 7 (Jeekel 1982: 127). The specimens described in 2002 also differ from S. pruvoti in lacking dark transverse annulation (Jeekel 2002: 61). Both Brolemann (1931: 295, for S. pruvoti) and Verhoeff (1941: 11, for $S$. annulatus) note strongly contrasting annular rings of colour, and all non-type adults listed above are clearly ringed (Fig. 4A-B), apart from a decoloured male in QM S74859. Jeekel explained the difference in shape of the solenomere between $S$. pruvoti and the South Australian males (Fig. 6) by saying "It should be emphasised that the distal portion of the gonopod (i.e. the solenomerite) is quite flexible, and may be curving more or less widely in a caudal direction, and may be crooked at the base" (Jeekel 1982: 127). It is true that the $S$. pruvoti solenomere can be made to curve posteriorly by manipulation. However, in none of the preserved specimens I have so far examined of any Solaenodolichopus species is the solenomere 'naturally' curved as sharply as illustrated by Jeekel (Fig. 6C).

\section{General notes}

The collector of S. annulatus, Johan Mauritzon (1902-1950), was a lecturer in botany at Lund University when he travelled to Australia in 1936 in company with University of Uppsala zoologist Folke Linder (as reported in several contemporary Australian newspapers, e.g., The Adelaide Chronicle, 10 Sep. 1936: 52, http://trove.nla.gov.au/ndp/del/article/92463218, accessed 10 Oct. 2013). Mauritzon left Lund University soon after returning from his Australian trip (H. Wittzell, in litt. 10 Oct. 2013) and his Australian millipedes were later sent to Verhoeff from Lund by Torsten Gislén (Verhoeff 1941: 3). The types of $S$. annulatus and four other species described by Verhoeff (1941) from this material have not yet been located. The types may not have been returned to Lund, as none of the Mauritzon millipede specimens collected in Australia are currently in the Lund University Zoological Museum (J. Ekstrom, in litt. 13 Jan. 2014).

The reported type localities of two of Verhoeff's five 1941 species are incorrect, and it is unclear at which stage in the information chain from Mauritzon to Verhoeff the error appeared. Hoplatessara (Walestessara) forceps Verhoeff, 1941 (now Cladethosoma forceps) and Hoplatria clavigera Verhoeff, 1941 were both described from Mauritzon collections in Gippsland, a district in eastern Victoria. Both have since been collected in NSW west of Sydney, and neither has since been found in intensively collected parts of Gippsland. However, the 'Brisbane' type locality for S. annulatus is plausible, because Verhoeff (1941: 12) gives "XII.36" as the collecting date and there are "near Brisbane" locations for Mauritzon plant collections dated 22 Dec. 1936 in the NHRS Herbarium (http://www.nrm.se/english/ researchandcollections/collections/databases/kryptos.8598 en.html, accessed 12 Oct. 2013) and in the Uppsala Museum of Evolution (http://130.238.83.220/botanik/home.php, accessed 12 Oct. 2013).

Brolemann's 1931 paper is devoted to species collected by 'Mme. Pruvot', i.e., the malacologist Alice Pruvot-Fol (1873-1972), but Brolemann explicitly named Paraulacoporus pruvoti for Pruvot-Fol's late husband, the zoologist Georges Pruvot (1852-1924) (Brolemann 1931: 298).

Solaenodolichopus rubriventris Verhoeff, 1928

Figs 2B, 3A-B, 8A-B, E-I

Solänodolichopus rubriventris Verhoeff, 1928: 94 (genus misspelled Solanodolichopus), 95 (first description, name printed in error as Solandolichopus walesius, corrected in journal Corrigenda); 114 (as Solänodolichopus rubriventris in list of species described in paper); figs 24-25 in pl. 10.

Aulacoporus rubriventris - Attems 1937: 61 (new combination), 263 (Verhoeff's 1928 description reworded); fig. 330 (p. 265; same as fig. 24 in Verhoeff 1928). —Jeekel 1968: 18, 29; 1981: 49.

Parwalesoma rubriventris - Jeekel 2000: 41 (new combination), 43. —Nguyen \& Sierwald 2013: 1158. 

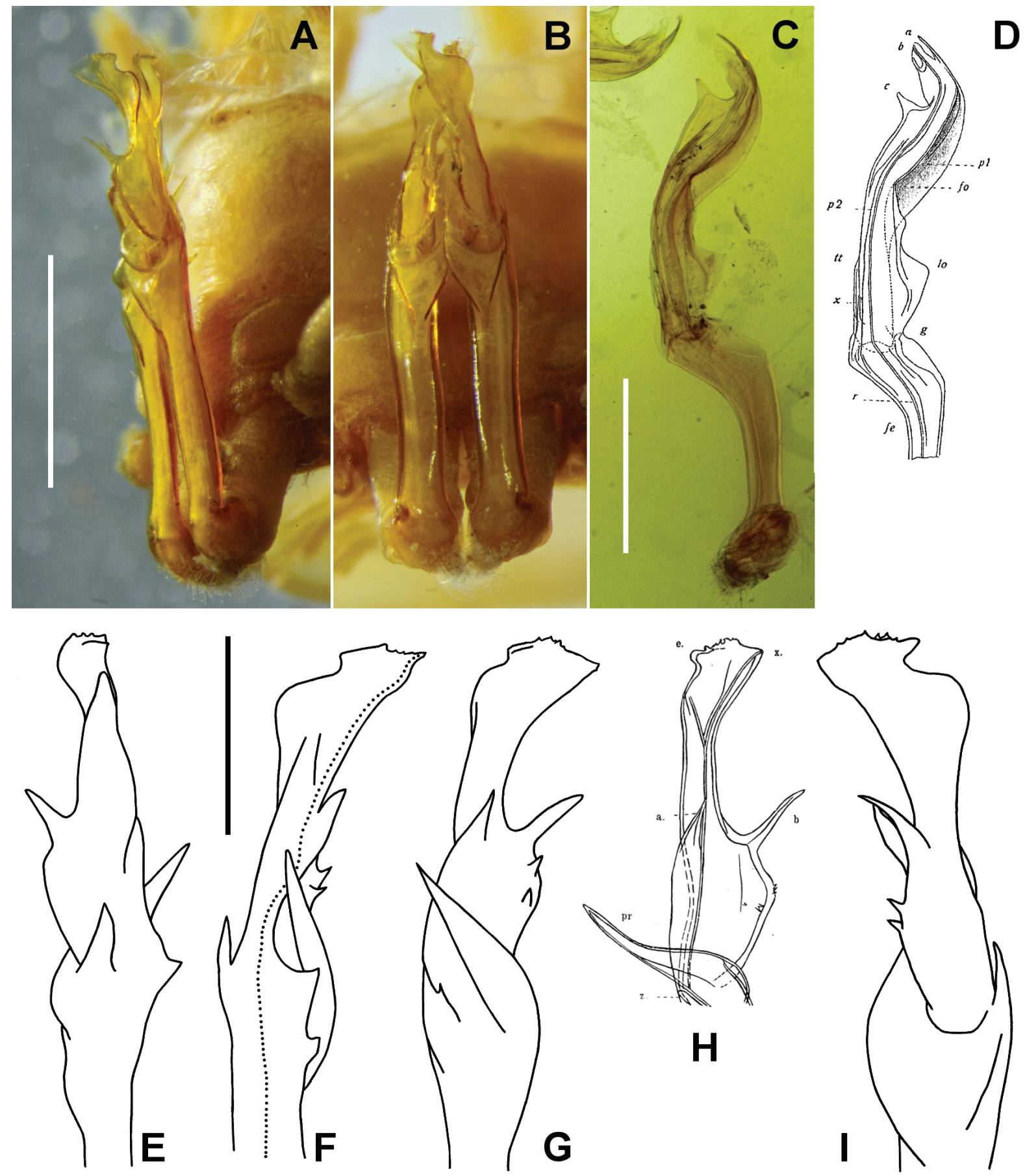

Fig. 8. - A-B, E-I. Solaenodolichopus rubriventris Verhoeff, 1928. Lateral (A) and posterior (B) views of gonopods in situ; left gonopod solenomere in lateral (E), anterior (F), medial (G), medial and slightly posterior (H) and posterior (I) views. A, B, E, F, G, I from QM S74690, H from fig. 24 in Verhoeff (1928). Dotted line in F marks course of prostatic groove. - C-D. S. teres (Verhoeff, 1924), anterior views of right gonopod telopodite of lectotype, from slide mount NHRS KAS1000000005 (C) and from fig. 7 in Verhoeff (1924) (D). Scale bars: A-B $=2 \mathrm{~mm}, \mathrm{C}-\mathrm{I}=1 \mathrm{~mm}$. 


\section{Material examined}

\section{Syntypes}

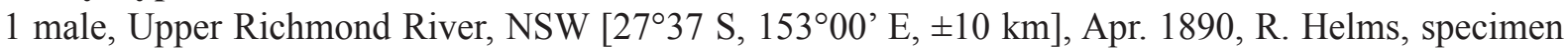
not located; 1 in alcohol with original Verhoeff label, broken between rings 11 and 12, same collection details, AM KS.76506 (formerly 47728); 1 female in alcohol with original Verhoeff label, broken between rings 7 and 8 and rings 11 and 12, same collection details, AM KS.76507 (formerly 47723); 1 female, same collection details, specimen not located.

\section{Other material}

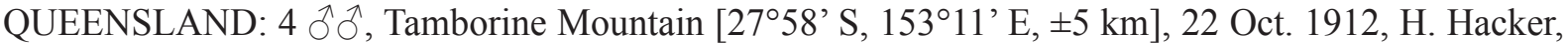

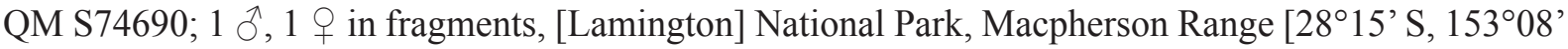
E, \pm 5 km], 15 Dec. 1926, P.A. Gilbert, AM KS.94916 (formerly K55468); 1 ô, Eagle Heights [2754' S, $153^{\circ} 12^{\prime} \mathrm{E}, \pm 5 \mathrm{~km}$ ], M.B. Man, 23 Mar. 1955, under logs, QM S74691; 1 §., Mt Tamborine [Tamborine Mountain] [27 $58^{\prime} \mathrm{S}, 153^{\circ} 11^{\prime} \mathrm{E}, \pm 5 \mathrm{~km}$ ], pitfall 15 Jan.-4 Mar. 1979, J. Grimshaw, rainforest, QM S74692.

\section{Description}

(Based on Mt Tamborine males and syntype females.) As for the genus. Maximum male/female midbody width $c a .5 .4 / 6.5 \mathrm{~mm}$. Colour in alcohol: "Back brownish black, without rings, only the abdomen passing into a wine red colour" (Verhoeff 1928: 94); the least faded of the specimens examined are more or less uniformly red-brown, darker dorsally, with a pale waist and yellow legs.

Male with with distinct transverse furrow on metazonites, stopping a little above level of ozopore. No longitudinal furrows laterally on diplosegments. Sternal lamella (Fig. 2B) with straight sides, corners broadly rounded, distal margin a flat inverted V. Scopulae on legs 1 to 29, i.e., not present on last podous ring. Leg bases on ring 6 separated a little more than on ring 5; leg bases with normal separation on ring 8. Anterior margin of aperture with rounded-triangular, medial extension and shorter, gently convex extension on either side (Fig. 3B).

Gonocoxa $c a$. 2/3 telopodite length, slightly flattened anteroposteriorly and slightly concave anteriorly, with sparse, long setae anterodistally. Cannula short, narrow, uniformly tapering towards prefemur. Gonopod telopodite (Fig. 8A-B, E-I) reaching leg 6 bases when retracted. Prefemur small, rounded, densely setose posteromedially, demarcated from femorite laterally by small, narrow notch. Remainder of telopodite more or less straight, slender, clearly divided into femorite and solenomere at just over $1 / 2$ telopodite length. Femorite straight, slightly flattened anteroposteriorly, parallel-sided in posterior view, apically thickened posteriorly as inverted triangle. Lateral femorite process small, pointed, toothlike, directed distally, $c a$. 1/5 solenomere length. Medial femorite process teardrop-shaped, arising near lateral process, the base expanded as thin, translucent cuticle, curving anterodistally and closely pressed to triangular apical thickening of femorite and to solenomere base, tapering to point just anterior to solenomere at $c a .1 / 2$ solenomere length. Solenomere arising from anterior side of femorite; slightly flattened anteroposteriorly with narrow, ridge-like thickening posteromedially; anteriorly with narrow flange of cuticle arising basomedially and produced basomedially as blunt point, and at $c a$. $1 / 3$ solenomere length as short, distally acuminate process; thin, spine-like process arising at $c a$. $1 / 2$ solenomere length from posteromedial ridge-like thickening, directed posterodistally and a little medially; ridge-like thickening extended slightly at $c a$. $1 / 4$ solenomere length and bearing several fine, tooth-like projections. Solenomere expanded from $c a$. 3/4 length, anteroposteriorly flattened, the apex rounded laterally, medially extended as lamellar, posteromedially directed triangle, the apical margin of triangle expanded as narrow, basodistally flattened shelf tapering towards medial apex of triangle, and 
finely dentate medially. Prostatic groove (Fig. 8F) running just lateral to flange on anterior surface of solenomere, terminating at apex of triangular apical tab.

Female without process on leg 2 coxa.

\section{Distribution}

Known from the forested mountains behind the Gold Coast in southeast Queensland south across the Border Ranges to the Richmond River catchment in NSW, a north-south extent of at least $60 \mathrm{~km}$ (map Fig. 12). Overlaps in range with $S$. vittatus.

\section{Taxonomic notes}

Verhoeff (1928: 96) wrote that he examined one male and three females, but I have not located either the male or a third female. With the male missing, I am reluctant to designate one of the undescribed females as lectotype. My description of male S. rubriventris is based on Verhoeff's published notes and on the specimens listed above from Tamborine Mountain, $c a .80 \mathrm{~km}$ from the roughly approximated type locality (see below). The 1979 Tamborine Mountain male was identified as 'Atropisoma rubriventris' by P.M. Johns during a 1987 visit to QM.

\section{General notes}

S. rubriventris, $S$. sulcatus and $S$. walesius were among millipede specimens supplied to Verhoeff by Charles Anderson (Verhoeff 1928: 79), Director of the Australian Museum in Sydney from 1921 to 1940. Verhoeff's German manuscript on the material included descriptions of 21 new millipede species and subspecies. It was translated into English by Anderson for the Records of the Australian Museum and the draft translation was sent to Verhoeff for approval (Verhoeff 1928: 79). Some typographical errors in nomenclature escaped proofreading (see synonymy above) and some morphological terms were mistranslated. For example, Anderson consistently translated hinter in the sense of 'behind, posterior', even when Verhoeff used hinter to mean 'beyond, distal' (as in English 'hinterland').

Although Richard Helms (1842-1914) had been working as a collector for the Australian Museum in Sydney in 1888 and 1889, he had gone to the Richmond River in 1890 "in the interest of a private syndicate" (Hedley 1915: 13). I have not been able to find a report by Helms on the Upper Richmond River trip. According to local historian Margaret Henderson (in litt., 9 Jan. 2006), "The 'Upper Richmond River' usually refers to the area from Casino to the source in the ranges". I place the collections very approximately at Kyogle, about halfway between Casino and the Border Ranges and $c a .30 \mathrm{~km}$ upstream from Casino.

Solaenodolichopus sulcatus (Verhoeff, 1928)

Figs 2C, 9

Paraulacoporus sulcatus Verhoeff, 1928: 93 (first description); fig. 11 in pl. 7.

Solaenodolichopus sulcatus - Jeekel 2000: 41 (new combination), 42, 43 (redescription from new material); figs 3-5 (p. 48) (see taxonomic notes, below). — Nguyen \& Sierwald 2013: 1160.

Paraulacoporus sulcatus - Verhoeff 1932: fig. 969 (p. 1577).

Aulacoporus sulcatus - Attems 1937: 261 (new combination), 262 (Verhoeff's 1928 description reworded); fig. 326 (p. 262; same as fig. 11 in Verhoeff 1928). — Jeekel 1968: 18, 29; 1981: 49. 


\section{Material examined}

Lectotype (here designated)

Male in alcohol with original Verhoeff label, broken between rings 8 and 9 and rings 11 and 12, North Dorrigo, NSW [ $30^{\circ} 16^{\prime} \mathrm{S}, 152^{\circ} 41^{\prime} \mathrm{E}, \pm 5 \mathrm{~km}$ ], 4 Jan. 1923, A. Musgrave, AM KS.76503 (formerly K47706).

\section{Paralectotype}

1 male, details as for lectotype, not located (see taxonomic notes, below).
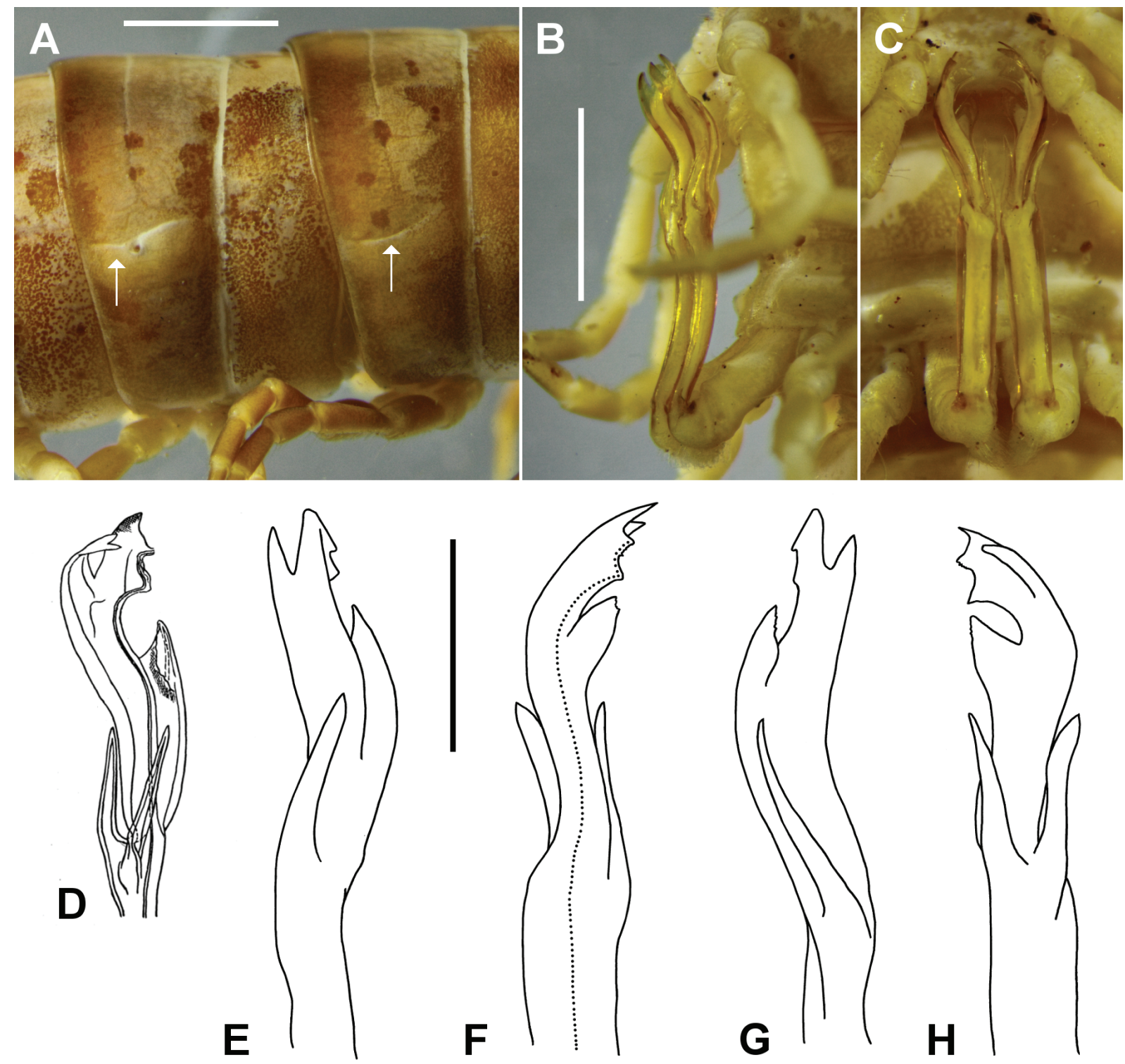

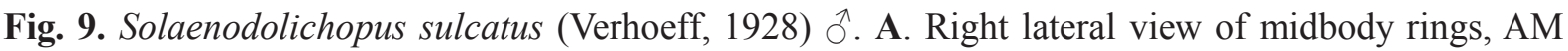
KS.77379. B-C. Lateral (B) and posterior (C) views of gonopods in situ, lectotype, AM KS.76503. D. Posterior and slightly medial view of right gonopod solenomere, possibly of missing paralectotype, from fig. 11 in Verhoeff (1928). E-H. Lateral (E), anterior (F), medial (G) and posterior (H) views of left gonopod solenomere, QM S75836. Arrows in A point to longitudinal grooves, dotted line in F marks course of prostatic groove. Scale bars: A-C $=2 \mathrm{~mm}, \mathrm{D}-\mathrm{H}=1 \mathrm{~mm}$. 


\section{Other material}

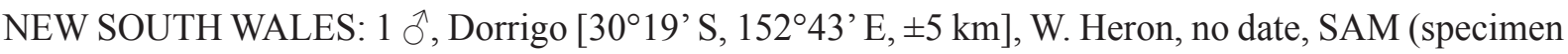
missing; described in Jeekel 2000); $1 \mathrm{O}^{\top}$, Upper Styx State Forest - Petroi Forest [ $30^{\circ} 40^{\prime} \mathrm{S} 152^{\circ} 08^{\prime} \mathrm{E} \pm 10$ km], 29 Jan. 1975, P. Johns and R. Killip, Nothofagus moorei forest, QM S75836; 1 ðૈ, Bruxner Forest

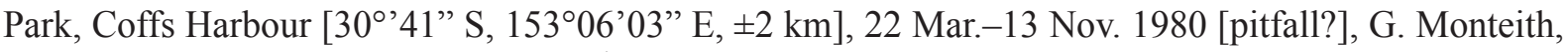
sample GM 104 A/1, QM S75837; 1 ô, Leagues Scrub Flora Reserve, Oakes State Forest, 30³6' S, $152^{\circ} 32^{\prime}$ E [ \pm 2 km], 780 m, 20-21 Dec. 1998, D. Bickel, yellow pan, rainforest, AM KS.77379.

\section{Description}

As for the genus. Maximum midbody width $c a .5 .0 \mathrm{~mm}$. Colour in alcohol: "Body brownish black, greyish-yellow on the abdomen, back with rather broad yellowish median band, which continues over the pro- and meta-zonites [sic] to the telson. Legs black, brownish on the joints" (Verhoeff 1928: 93); lectotype colour now faded, prozonites light brown, metazonites and legs yellowish, pale mid-dorsal longitudinal band $c a$. 1/5 maximum ring width at midbody; more recent specimens also faded, patchy brown with pale mid-dorsal band as in lectotype.

Male lectotype with distinct transverse furrow on metazonites, stopping a little above level of ozopore (Fig. 9A). Distinct longitudinal furrows on diplosegments (Fig. 9A) to ring 15, rising slightly anteriorly, opening dorsally with very slight bulges below; furrow just above ozopore on pore-bearing rings. Sternal lamella (Fig. 2C) rounded-rectangular, distal margin very slightly convex. Scopulae on legs 1 to legs of ring 14 (lectotype) or 15 or 16 (other males examined). Leg bases on ring 6 separated a little more than on ring 5; leg bases with normal separation on ring 8 . Anterior margin of aperture more or less straight with small, rounded-triangular, medial extension.

(Gonopod description based on lectotype and other males.) Gonocoxa a little more than 1/2 telopodite length, slightly flattened anteroposteriorly and slightly concave anteriorly, with sparse, long setae anterodistally. Cannula short, narrow, uniformly tapering towards prefemur. Gonopod telopodite (Fig. 9B-H) reaching leg 6 bases when retracted. Prefemur small, rounded, densely setose posteromedially, demarcated from femorite laterally by small, narrow notch. Remainder of telopodite more or less straight, slender, clearly divided into femorite and solenomere at just over $1 / 2$ telopodite length. Femorite slightly flattened anteroposteriorly, slightly concave posteriorly in lateral view, parallel-sided in posterior view, apically a little thickened posteriorly. Femorite processes both about $1 / 3$ solenomere length, tapering with rounded tips; lateral process curving a little anterolaterally, medial process curving a little anteriorly. Solenomere $c a$. 2/3 femorite width at base, curving slightly anterolaterally, then posteromedially, flattened to form trough-like hollow, concave posteromedially; basal half of anterior margin of hollow produced mediodistally as large, flat, extension with tapering, rounded tip at $c a$. 3/4 solenomere height; distomedially curving solenomere apex deeply notched to form rounded posterior point separate from anteroposteriorly flattened anterior margin of hollow, the latter produced apically as thin, subtrapezoidal tab, its medial margin roundly emarginate. Prostatic groove (Fig. 9F) running on anterior surface of telopodite, following curve of solenomere to basal corner of subapical, anterior margin tab, bending distally at right angle and opening at distal corner of tab.

Female not yet recognised.

\section{Distribution}

Rainforest (and eucalypt forest?) in northeast NSW from the Coffs Harbour area inland towards Armidale, an east-west extent of $c a .90 \mathrm{~km}$, at elevations to at least $780 \mathrm{~m}$ a.s.l. (map Fig. 12). Overlaps in range with $S$. walesius. 


\section{Taxonomic notes}

Verhoeff (1928: 94) reported that he examined two males, but I have not located a second specimen. The lectotype vial contains a label with 'LECTOPARATYPE / ô P.M. Johns / 19.xii.67', suggesting that Johns may have found another male or slide mount of male parts and labelled it 'lectotype'; this lectotypification has not been published.

In fig. 11 of Verhoeff(1928), reproduced here as Fig. 9D, the rounded posterior process at the solenomere apex is shown as apically notched. This appears to be an error, as the process is not notched at its tip in the lectotype or any of the other three available S. sulcatus males. Jeekel (2000) described a fourth male, from Dorrigo (NSW); his gonopod illustration (Jeekel's fig. 5: 48) also shows the posterior process without a notch. The Dorrigo male was borrowed from SAM but is currently missing from the Museum collection (K. Sparks, in litt., 2 Jan. 2014).

\section{General notes}

The collector of the types Anthony Musgrave (1895-1959) worked as an entomologist at the Australian Museum from 1920 until his death (http://adb.anu.edu.au/biography/musgrave-anthony-7716; accessed 30 Dec. 2013). He specialised in the taxonomy of arachnids, Diptera and Hemiptera, and is best known as the compiler of a monumental bibliography of Australian entomology (Musgrave 1932). Musgrave's 1923 North Dorrigo trip also yielded the types of S. walesius Verhoeff, 1928 (see below).

See also the general notes for $S$. rubriventris (above).

Solaenodolichopus teres (Verhoeff, 1924)

Figs 1D, 2D, 3D, 8C-D

Antichiropus (Solänodolichopus) teres Verhoeff, 1924: 12 (as Antichiropus teres), 20 (as Solänodolichopus teres in key), 21 (as Antichiropus (Solänodolichopus) teres, first description); figs 7-8 in pl. 1.

Aulacoporus teres Attems 1937: 261 (new combination), 263 (Verhoeff's 1924 description reworded); fig. 327 (p. 263; same as fig. 7 in Verhoeff 1924).

Solaenodolichopus teres - Verhoeff 1928: 94 (genus misspelled Solanodolichopus; new combination for teres, vittatus and vittatus dorsalis, referred to by Verhoeff as "the three forms previously described by me"). — Jeekel 2000: 40. — Nguyen \& Sierwald 2013: 1159.

Aulacoporus teres - Attems 1937: 261 (new combination), 263 (Verhoeff's 1924 description reworded); fig. 327 (p. 263; same as fig. 7 in Verhoeff 1924). — Jeekel 1968: 18, 29; 1971: 233 (designated as type of Solaenodolichopus); 1981: 49.

\section{Material examined}

\section{Lectotype (here designated)}

Slide mount with original Verhoeff label containing male legpair 1, right gonopod telopodite, left gonopod telopodite missing prefemur, left gonopod prefemur attached to the distal portion of the gonocoxa, both legs 9 and a cuticle fragment which may be the anterior aperture margin from ring 7, NHRSKAS1000000005; the rest of the male body missing legpair 1, ring 7 and parts of some legs, in alcohol

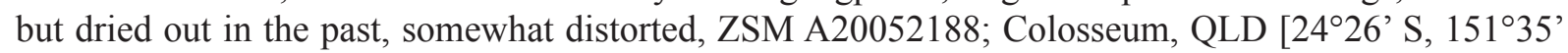
E, \pm 5 km], E. Mjöberg, Nov.-Dec. 1912 (see taxonomic notes, below). The lectotype is the one male specimen examined by Verhoeff, i.e., the body parts on the slide mount plus the body parts in alcohol.

\section{Paralectotype}

Female, details as for lectotype, in alcohol, body broken between rings 8 and 9, NHRS-KAS1000000007. 


\section{Other material}

None.

\section{Description}

As for the genus. Maximum midbody width $c a .3 .0 / 3.5 \mathrm{~mm}$ (male lectotype/female paralectotype, but male distorted by drying out in past). Colour in alcohol: "Body gray-yellow, on each side with wide brown longitudinal band dorsally, becoming dark brown anteriorly. Between the brown longitudinal bands a washed-out ochre-yellow dorsal longitudinal band with a brown median stripe. Collum dark brown, medially more or less lighter" (Verhoeff 1924: 20, my translation); male lectotype largely colourless, female paralectotype dull yellow grading to light reddish-brown posteriorly on each ring with no trace of longitudinal banding.

Male with transverse furrow on metazonites, stopping well above level of ozopore. No longitudinal furrows laterally on diplosegments. Sternal lamella (Fig. 2D) rounded-rectangular, with near-vertical sides and more or less straight distal margin slightly raised as small, rounded projection in centre, and with wide, shallow concavity on posterior surface on either side. Aperture details uncertain due to Verhoeff's dissection, but if slide-mounted cuticle fragment is anterior margin of aperture, then with gently convex extensions to anterior aperture margin on either side of rounded-triangular, medial extension (as shown in Fig. 3B for S. rubriventris). Scopulae on legs 2-29, i.e., not present on first or last podous rings.

Gonopod telopodite reach on venter uncertain due to dissection, and not stated by Verhoeff (1924). Gonocoxa length relative to telopodite not known; gonocoxa fragment on lectotype slide with sparse, long setae anterodistally. Cannula short, narrow, uniformly tapering towards prefemur. Prefemur small, rounded, densely setose posteromedially, demarcated from femorite laterally by small, narrow notch. Femorite (Fig. 8C) ca. 40\% of telopodite length, somewhat flattened anteroposteriorly, more or less uniformly wide to $c a$. $1 / 2$ its length, then bending medially at $c a .45^{\circ}$ and expanding, the end more or less truncate. Lateral femorite process represented by small, short, rounded ridge at femorite tip. Medial femorite process short, pointed, "thrust into a groove on the medial side of the base of the solenomerite and is therefore easily overlooked" (Verhoeff 1924: 21, my translation). Solenomere (Fig. 8C-D) at base $c a$. $1 / 2$ femorite tip width, directed distally and curving laterally at midlength, distally flattened anteroposteriorly, the lateral profile gently convex; anterior surface with thin, ridge-like flange along almost entire length of solenomere, extended anterolaterally as large triangle near base and smaller triangle just below midlength. Solenomere distomedially with U-shaped indentation, the basal rim of the $\mathrm{U}$ extending as short, tooth-like projection. Solenomere distal from U curving medially, subdivided by narrow indentation into short, rod-like apical process and anteroposteriorly flattened, truncate, subapical process with opening of prostatic groove in middle of medial margin. Prostatic groove running on anterior surface of telopodite, following curve of solenomere on medial side of anterior surface flange.

Female paralectotype with distolateral process (Fig. 3D) on each leg 2 coxa extending $c a .1 / 2$ coxa diameter laterally, with truncate lateral margin about coxa diameter in length; in situ the process resting on ring 3 ventral surface posterior to raised end of epigyne.

\section{Distribution}

So far known only from the type locality in central coastal Queensland (map Fig. 12).

\section{Taxonomic notes}

Verhoeff based his description on one male and one female. He also examined a female $20 \mathrm{~mm}$ long, but questioned whether it belonged to the same species (Verhoeff 1924: 22). The small female is a stadium 
7 individual broken between rings 7 and 8 and is in the NHRS vial with the paralectotype. The lectotype slide was labelled 'lectotype' by P.M. Johns in 1967, but Johns did not publish this lectotypification.

Verhoeff (1924) did not give a collection date for the $S$. teres syntypes. Mjöberg's unpublished field diaries show that he arrived in Colosseum in the last week of November 1912 and left during the first week of December 1912 (A. Ferrier, in litt., 16 Dec. 2013; see also Ferrier 2006).

The structure of the gonopod telopodite is a little unclear to me due to its flat mounting on a microscope slide, and I have not yet seen any other Solaenodolichopus specimens with gonopods perfectly matching those of S. teres. A male (QM S74768) pitfall-trapped in 1983 at Kroombit Tops, ca. $60 \mathrm{~km}$ west of Colosseum, has a similarly short and distally bent femorite and might be conspecific. However, the much-faded colouring of the Kroombit Tops male consists of brown transverse bands at the rear of the metazonites against a pale yellow ground, rather than the longitudinal banding seen by Verhoeff in $S$. teres. The medial femorite process in the Kroombit Tops male has a teardrop-shaped base as in S. pruvoti (for example); details of the base are unclear in the slide-mounted $S$. teres gonopods.

\section{General notes}

S. teres, S. vittatus Verhoeff, 1924 and S. vittatus dorsalis Verhoeff, 1924 were among specimens collected by the Swedish zoologist Erik Mjöberg (1882-1938) during two expeditions to Australia, 1910-1913 (Ferrier 2006). Verhoeff obtained the Mjöberg specimens from the Naturhistoriska Riksmuseet in Stockholm, described 43 new millipede species and subspecies from the material and published his results in the Swedish journal Arkiv för Zoologi (Verhoeff 1924). To Verhoeff's disappointment, the journal reproduced many of his drawings at a scale too small for clarity, among them those of Aulacoporus and Solaenodolichopus spp.: "Die Abbildungen sind leider etwas zu stark verkleinert worden, wodurch die Deutlichkeit mancher zarterer Teile gelitten hat" (Verhoeff 1924: 142).

Solaenodolichopus vittatus (Verhoeff, 1924)

Figs 1C-E, 2E, 10B-G

Antichiropus (Solänodolichopus) vittatus Verhoeff, 1924: 22 (first description); pl. 1, figs 5, 9, 10.

Antichiropus (Solänodolichopus) vittatus dorsalis Verhoeff, 1924: 21, 22 (first description); pl. 1, fig. 6 [New synonymy.]

Solaenodolichopus vittatus - Verhoeff 1928: 94 (genus misspelled Solanodolichopus; new combination for teres, vittatus vittatus and vittatus dorsalis, referred to by Verhoeff as 'the three forms previously described by me'). — Jeekel 2000: 40. — Nguyen \& Sierwald, 2013: 1160.

Aulacoporus vittatus - Attems 1937: 261 (new combination), 263 (Verhoeff's description reworded); fig. 328 (p. 263; same as fig. 6 for S. vittatus dorsalis in Verhoeff 1924). — Jeekel 1968: 18, 29; 1981: 49.

Aulacoporus vittatus dorsalis - Verhoeff 1928: 94 (genus misspelled Solanodolichopus; new combination for teres, vittatus vittatus and vittatus dorsalis, referred to by Verhoeff as 'the three forms previously described by me'). - Attems 1937: 261 (new combination), 264 (Verhoeff's description reworded). Jeekel 1968: 18, 29; 1981: 49.

Solaenodolichopus vittatus dorsalis - Jeekel 2000: 40. — Nguyen \& Sierwald 2013: 1160.

\section{Material examined}

S. vittatus lectotype (here designated)

Slide mount with original Verhoeff label, containing male legpair 1, right gonopod, left gonocoxa, left gonopod telopodite and 1 leg 9, NHRS KAS1000000004; and the rest of the male body in alcohol with original Verhoeff label, missing legpair 1, body broken between rings 3 and 4, rings 6 and 7, and rings 
8 and 9, NHRS KAS1000000006; Mt Tambourine [Tamborine Mountain], QLD [2758' S, $153^{\circ} 11^{\prime} \mathrm{E}$, $\pm 5 \mathrm{~km}$ ], E. Mjöberg, Oct. 1912 (see taxonomic notes, below). The lectotype is the one male specimen examined by Verhoeff, i.e. the body parts on the slide mount plus the body parts in alcohol.

\section{S. vittatus paralectotype}

Female, details as for lectotype, body broken between rings 3 and 4 and rings 5 and 6 , in alcohol, NHRS KAS1000000006.

\section{S. vittatus dorsalis holotype}

Slide mount with original Verhoeff label, containing male legpair 1, both gonopod telopodites, 1 gonocoxa and both legs 9; and the rest of the male body in alcohol with original Verhoeff label, broken into head + collum and rings 3,4+5, 6+7, 8, 9+10, 11-13 and 14-telson, missing legpair 1 and legs and gonopods from ring 7, aperture damaged; Glen Lamington [Lamington Glen], QLD [28 ${ }^{\circ} 15^{\prime} \mathrm{S}, 153^{\circ} 01^{\prime}$ E, \pm 5 km], E. Mjöberg, Nov. 1912 (see taxonomic notes, below). The holotype by monotypy is the one male specimen examined by Verhoeff, i.e. the body parts on the slide mount plus the body parts in alcohol, both in NHRS and registered as KAS1000000003.

\section{Other material}

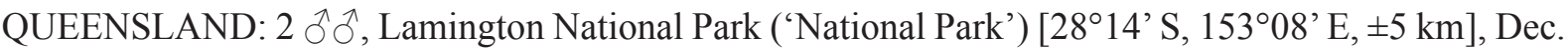

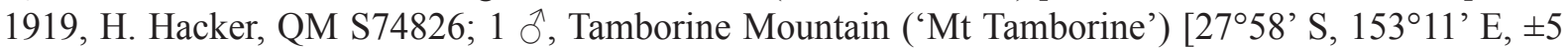
km], Oct. 1924, A. Musgrave and G. Geissmann, QM S74827; 1 ô, same locality but 18 Mar. 1955, M.B. Wilson, in grass, QM S74764; 1 ô, 1 क , same locality but 26 Mar. 1955, S.B. Gunn, QM S74829;

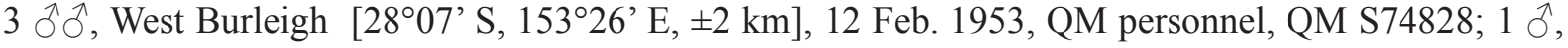
Warrie National Park [28¹3' S, $153^{\circ} 16^{\prime}$ E, \pm 2 km], 2 Jul. 1971, K.R. McDonald, rainforest, under

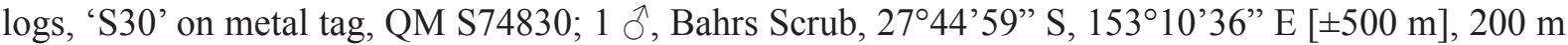
a.s.l., pitfall, 29 Jan.-23 May 1981, G. Monteith, GM 1078/2, QM S74765; 1 §̊, Moreton Island, 27¹1' S, $153^{\circ} 24^{\prime}$ E [ \pm 10 km], 26 Apr. 1982, W. Houston, pitfall, yellow patch, EIS, QM S5941; 1 đે, Blue Lagoon, Moreton Island, $27^{\circ} 05^{\prime} 35^{\prime}$ ' S, 153 $26^{\prime} 27^{\prime \prime}$ E [ $\pm 2 \mathrm{~km}$ ], 21 Sep. 1982, W. Houston, EIS, pitfall,

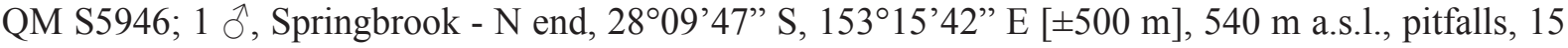
May-30 Aug. 1997, G. Monteith, rainforest, sample 5015, QM S74836; 1 ○े, Perrys Knob, 27³6’11” S, 152 36'17' E [ \pm 500 m], 200 m a.s.l., pitfall, 15 Sep-11 Nov. 1998, G. Monteith, D. Cook and G. Thompson, vine scrub, sample 7295, QM S74843; 1 ð, same details but pitfall, 11 Nov. 1998-13 Jan.

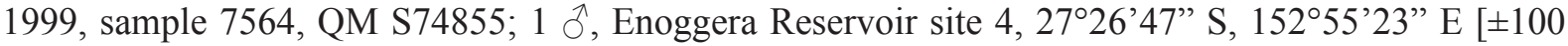
m], 110 m a.s.l., pitfall, 7 Aug.-16 Oct. 1999, G. Monteith and J. Holt, rainforest, sample 7854, QM

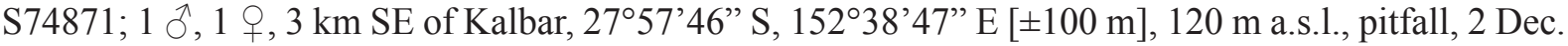
2000-7 May 2001, C. Burwell, sample 10160, brigalow scrub, QM S74766; 1 đ, Karawatha Forest - site 6, 27³7’33” S, 153 5’24" E [ $\pm 100 \mathrm{~m}$ ], 60 m a.s.1., 30 Apr. 2003, S. Wright and E. Volschenk, eucalypt

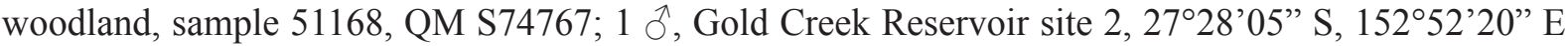
[ $\pm 100 \mathrm{~m}], 160 \mathrm{~m}$ a.s.l., 4 Nov. 2003, C. Burwell, dry rainforest, sifted litter berlesate, sample 51723, QM

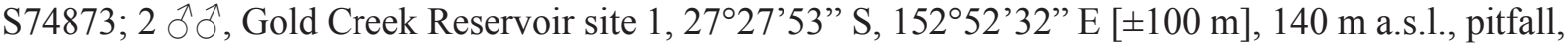
2-30 Jan. 2004, Queensland Museum personnel, spotted gum open forest, sample 51819, QM S74875; 1 đ, 2 우오, same details but 30 Jan.-1 Mar. 2004, sample 51939, QM S74876; 2 $\widehat{\partial}$, Welsby Street, New Farm [27²7’58” S, 15302’56” E, \pm 500 m], 1 Nov. 2010, M. Shaw, pitfall, QM S95213.

\section{Description}

As for the genus. Maximum male/female midbody width $c a .3 .8$ (mean of 24 males, range 2.9-4.7 $\mathrm{mm}) / 4.8 \mathrm{~mm}$ (paralectotype female). Colour in alcohol: "Body reddish yellow with two broad, blackish, lateral longitudinal bands on the dorsum, separated by wide, reddish yellow median (band). Medial [longitudinal] stripe washed-out reddish, ventral flanks reddish-yellow" (vittatus, Verhoeff 1924: 20, my translation); "Trunk black, with brown legs and wide yellow reddish dorsal median band, significantly 
narrower than in vittatus. Ventral flanks black" (vittatus dorsalis, Verhoeff 1924: 21, my translation); colour in types faded and patchy, dorsalis medial longitudinal band $c a .1 / 3$ ring width, vittatus $c a .2 / 3$ ring width; colour and pattern variable in other specimens (Fig. 4C-I), but always with lighter colouring dorsally and darkest colouring on upper sides.

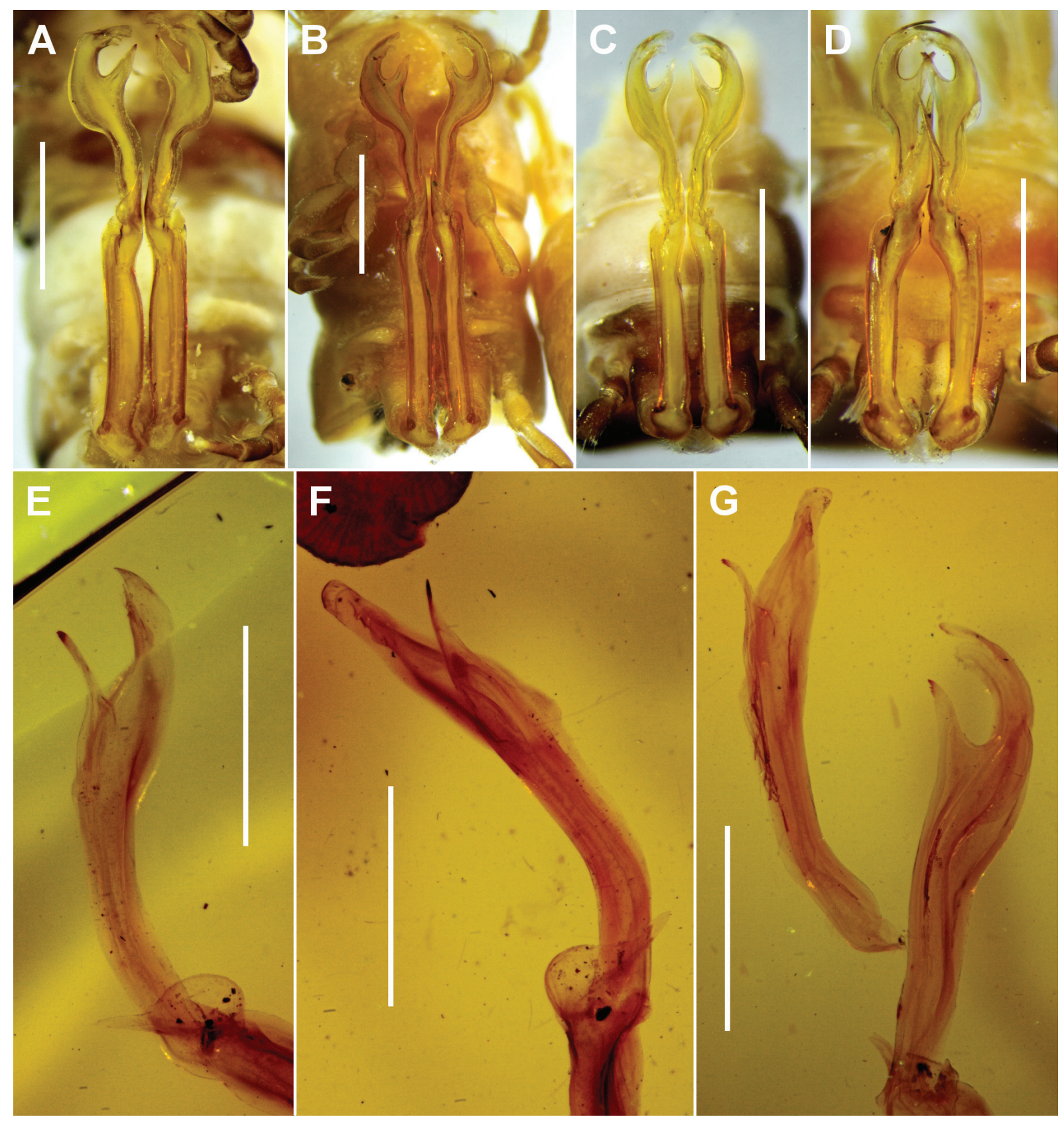

Fig. 10. A. - Solaenodolichopus pruvoti (Brolemann, 1931), posterior view of gonopods in situ, QM S74858. - B-G. S. vittatus (Verhoeff, 1924). B-D, posterior view of gonopods in situ; QM S74826 (B), QM S95213 (C), QM S74767 (D). E-G, views of slide-mounts; left (E) and right gonopod solenomere (F) of S. vittatus lectotype, NHRS KAS1000000004, and left (top left) and right (bottom right) gonopod solenomere $(\mathrm{G})$ of $S$. vittatus dorsalis holotype, NHRS KAS1000000003. Scale bars: A-D = $2 \mathrm{~mm}, \mathrm{E}-\mathrm{G}$ $=1 \mathrm{~mm}$. 
Male with transverse furrows shallow, narrow, sometimes indistinct. No longitudinal furrows laterally on diplosegments. Sternal lamella (Fig. 2E) with sides more or less straight, corners broadly rounded, distal margin a flat inverted V. Scopulae on legs 1 to 29, i.e., not present on last podous ring. Leg bases on rings 6 and 8 separated more widely than on other rings, sternites a little depressed. Anterior margin of aperture with rounded-triangular, medial extension and shorter, gently convex extension on either side (as shown in Fig. 3B for $S$. rubriventris).

Gonopods usually as for S. pruvoti (Fig. 10A), but with femorite in some males thinner (Fig. 10B), and in other males shorter and bent medially near apex, and with medial femorite process larger, reaching to ca. 1/3-1/2 of solenomere length (Fig. 10D); intermediate forms occur (Fig. 10C).

Female with leg 2 coxa extended posteroventrally as apically rounded process (as shown for $S$. pruvoti in Fig. 5C-D).

\section{Distribution}

Forest and non-forest habitats in the Brisbane region, from Moreton Island $c a .130 \mathrm{~km}$ south to the Border Ranges, and inland ca. $80 \mathrm{~km}$ from the sea (map Fig. 12). Overlaps in range with S. pruvoti and S. rubriventris.

\section{Taxonomic notes}

The subspecies $S$. vittatus dorsalis was erected for a single male only differing from $S$. vittatus vittatus in size, colour of ventral flanks and width of the medial dorsal band. These three characters vary substantially in the 24 non-type males I have examined and do not appear to be correlated. I therefore regard the subspecies dorsalis as a synonym of the nominate subspecies vittatus. The gonopod telopodites of the types are virtually identical (Fig. 10E-G).

S. vittatus varies more across its range than other Solaenodolichopus (described and undescribed), in gonopod form as well as in size and colour pattern. It might better be called 'the $S$. vittatus group', and intensive sampling and genetic analysis across its range would be a worthwhile systematics project.

It is particularly interesting that the gonopods in S. pruvoti and some S. vittatus populations are indistinguishable, and that no colour pattern intermediates have so far been found. When redescribing $S$. pruvoti as S. annulatus, Verhoeff wrote: "Stands close to vittatus Verh. (contribution 3, figs 9 and 10) but is distinguished by different patterning and some special features of the gonopods: the rudiment of the tibiotarsus [rounded process on basal side of U-shaped indentation] is smaller in vittatus and not curved, the parsolenomere [apical tab] very similar but more transversely curved, the medial displacement of the solenomere is barely detectable, overall the solenomere is less curved and less clavate, the end in vittatus rounded" (Verhoeff 1941: 12, my translation). These small differences are largely contained within the variation seen in both $S$. pruvoti and $S$. vittatus. Until new diagnostic features are identified, S. vittatus and $S$. pruvoti are only separable on colour pattern.

Both Verhoeff and Mjöberg spelled the type locality of S. vittatus 'Mt Tambourine', which in the early 20th century referred to both a village and to the small basalt plateau on which the village was located; the modern name for the plateau is Tamborine Mountain. Verhoeff (1924) did not give a collection date for the S. vittatus types. Mjöberg's unpublished field diaries show that he collected at 'Mt Tambourine' in the last two weeks of October 1912 ( $\AA$. Ferrier, in litt., 16 Dec. 2013; see also Ferrier 2006). The lectotype slide of $S$. vittatus was labelled 'lectotype' by P.M. Johns in 1967, but Johns did not publish this lectotypification. 
Verhoeff's one specimen of $S$. vittatus dorsalis was from 'Glen Lamington'. Lamington Glen was a locality and rainfall recording station on the Lamington Plateau in the first half of the 20th century, and Mjöberg's unpublished field diaries show that he collected on the 'Lamington Plateau' in mid-November 1912 ( $\AA$. Ferrier, in litt., 16 Dec. 2013; see also Ferrier 2006). The holotype slide was labelled 'holotype' by P.M. Johns in 1967.

\section{General notes}

See general notes for $S$. teres (above).

Solaenodolichopus walesius Verhoeff, 1928

Figs $1 \mathrm{~A}-\mathrm{B}, 2 \mathrm{~F}, 3 \mathrm{C}, 11 \mathrm{~A}-\mathrm{C}, 11 \mathrm{E}-\mathrm{I}$

Solänodolichopus walesius Verhoeff, 1928: 94 (genus misspelled Solanodolichopus), 95 (first description, genus misspelled Solandolichopus), 114 (as Solänodolichopus walesius in list of species described in paper); pl. 10, figs 26-27.

Parwalesoma castaneum Verhoeff, 1937: 139 (first description); figs 6-7 (p. 138).

Parwalesoma castaneum - Attems 1940: 549 (Verhoeff's description reworded). - Jeekel 1968: 19, 29. - Jeekel 1971: 231 (noted as type of Parwalesoma). - Jeekel 1981: 49. - Jeekel 2000: 41 (synonymised with Parwalesoma walesium). - Nguyen \& Sierwald 2013: 1157 (as synonym of Parwalesoma walesium).

Aulacoporus walesius - Attems 1937: 261 (new combination), 264 (Verhoeff's 1928 description reworded); fig. 329 (p. 264; same as fig. 26 in Verhoeff 1928). — Jeekel 1968: 18, 29; Jeekel 1981: 49. Parwalesoma walesium - Jeekel 2000: 41 (new combination). — Nguyen \& Sierwald 2013: 1157.

\section{Material examined}

S. walesius lectotype (here designated)

Male in alcohol with original Verhoeff label, broken between rings 6 and 7 and rings 7 and 8, North Dorrigo, NSW [30¹6’S 152 41' E \pm 5 km], 4 Jan. 1923, A. Musgrave, AM KS.76508 (formerly K47704).

\section{S. walesius paralectotypes}

1 male in alcohol with original Verhoeff label, broken between rings 6 and 7, ZMB 7962; 1 female in alcohol without original Verhoeff label, broken between rings 5 and 6, AM KS.76509 (also formerly K47704); collection details for both as for $S$. walesius lectotype.

P. castaneum lectotype (here designated)

Male in alcohol with original Verhoeff label, broken between rings 8 and 9, missing left antenna, ZMB

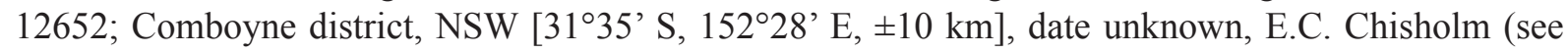
general notes, below).

\section{P. castaneum paralectotypes}

Slide mount with original Verhoeff label containing male legpairs 1 and 9 and both gonopods, ZSM A20033565; male rings 4-6 and an isolated diplosegment, and 1 female broken between rings 8 and 9, and 10 and 11, in alcohol with new labels (male and female in separate vials), ZSM 20052246; 1 female in alcohol with original Verhoeff label, broken between rings 6 and 7 and rings 12 and 13, AM KS76700; collection details for all three as for P. castaneum lectotype. I assume that the male rings in ZSM A20052246 and the slide-mounted parts in ZSM A20033565 are from the same individual, i.e., that together they represent a single male paralectotype specimen (see taxonomic notes, below). 

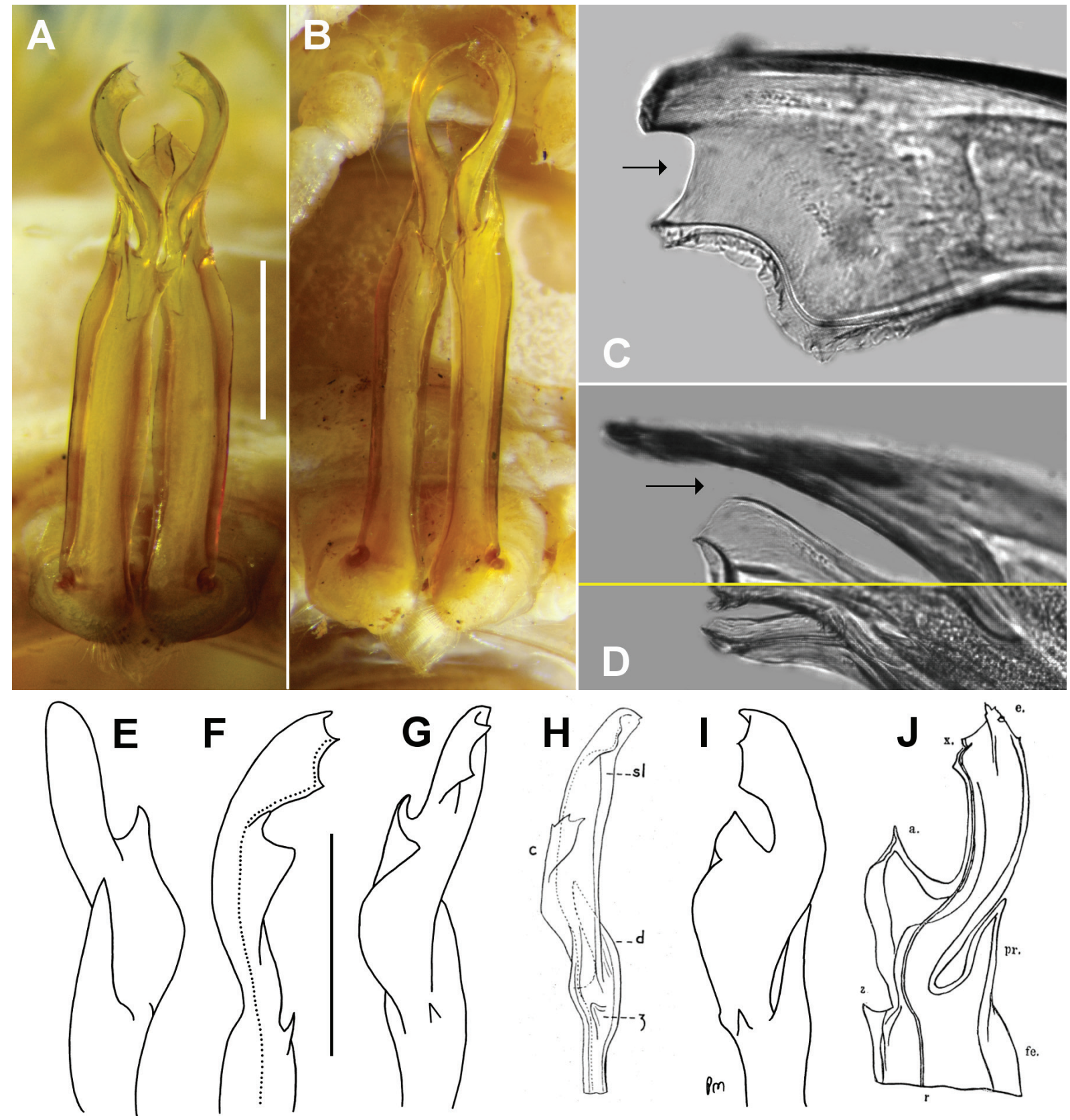

Fig. 11. - A-C, E-J. Solaenodolichopus walesius Verhoeff, 1928. A-B. Posterior views of gonopods in situ of lectotype, AM KS.76508 (A) and Parwalesoma castaneum Verhoeff, 1937 (= S. walesius) lectotype, ZMB 12652 (B). C. Posterior view of left gonopod solenomere tip, AM KS.16152. E-G, I. Lateral (E), anterior (F), medial (G) and posteromedial (I) views of left gonopod solenomere, AM KS.93755. H. Medial view of left gonopod solenomere of P. castaneum (= S. walesius), from fig. 6 in Verhoeff (1937). J. Posterior and slightly oblique view of left gonopod solenomere of S. walesius, from fig. 26 in Verhoeff (1928). - D. S. pruvoti (Brolemann, 1931), posterior view of left gonopod solenomere tip, QM S74856 (composite image at two focus levels). Dotted line in F marks course of prostatic groove. Scale bars: $1 \mathrm{~mm}$. 


\section{Other material}

NEW SOUTH WALES: 1 ơ $^{\wedge}$, Comboyne [ $31^{\circ} 35^{\prime} \mathrm{S}, 152^{\circ} 28^{\prime} \mathrm{E}, \pm 10 \mathrm{~km}$ ], Aug. 1926, E.C. Chisholm, AM

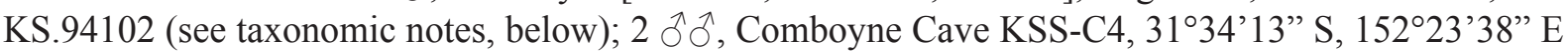

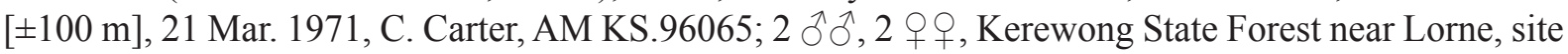
$108,31^{\circ} 36^{\prime} \mathrm{S}, 152^{\circ} 34^{\prime} \mathrm{E}$ [ $\pm 2 \mathrm{~km}$ ], pitfall, 7 Nov. -10 Dec. 1978, D. Milledge, AM KS.16152; 1 ơ, same details, KS.18483; 1 đo, same details but site $81,31^{\circ} 35^{\prime}$ S, $152^{\circ} 38^{\prime}$ E [ $\pm 2 \mathrm{~km}$ ], pitfall, 26 Sep. -12 Dec. 1978, AM KS.105104 (ex KS.96075); 1 ð̊, 2 우, Boundary Creek Road, Boundary Creek State Forest,

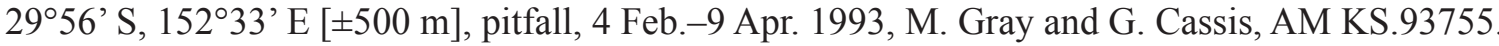

\section{Description}

(Based, unless otherwise indicated, on $S$. walesius lectotype and paralectotypes.) As for the genus. Maximum male/female midbody width ca. $4.5 / 4.5 \mathrm{~mm}$. Colour in alcohol: "Body ringed, the metazonites for the most part dark brown and the prozonites wine red. / The wine-red colour of the prozonites extends on to the anterior bands of the metazonites, which are otherwise dark brown. The lower sides and abdomen are also wine-red, the legs yellowish" (Verhoeff 1928: 94/95); colouring of types now faded and patchy, but rings light brown, darker dorsally, lightening to yellow at the waist, darkening towards rear of metatergite; colouring of more recent specimens as noted by Verhoeff.

Male with distinct transverse furrow on metazonites, stopping a little above level of ozopore. No longitudinal furrows laterally on diplosegments. Sternal lamella (Fig. 2F) broadly paraboloid in outline. Scopulae on legs 1 to 29, i.e., not present on last podous ring. Leg bases on ring 6 separated a little more than on ring 5; leg bases with normal separation on ring 8 . Anterior margin of aperture more or less straight with small, rounded-triangular, medial extension.

Gonocoxa (of male in AM KS.93755) about 1/2 telopodite length, slightly flattened anteroposteriorly, with sparse, long setae anterodistally. Cannula short, narrow, uniformly tapering towards prefemur. Gonopod telopodite (Fig. 11A-C, E-I) just reaching leg 6 bases when retracted. Prefemur small, rounded, densely setose posteromedially, demarcated from femorite laterally by small, narrow notch. Remainder of telopodite more or less straight, slender, clearly divided into femorite and solenomere at about $2 / 3$ telopodite length. Femorite narrowing very slightly between ends, slightly flattened anteroposteriorly. Medial femorite process a small, triangular tab; lateral femorite process spine-like, between 1/4 and $1 / 3$ solenomere length, arising more distally than medial process, curving slightly anteriorly towards solenomere. Solenomere arising anterior to femorite processes, $c a$. 1/2-2/3 femorite width at base, curving laterally then medially and flattening to form trough-like hollow, concave medially; basal half of anterior margin of hollow extending distomedially and a little anteriorly as large, flat, triangular tab reaching $\mathrm{ca}$. 1/2 solenomere length, curving posteriorly, distal margin of tab with a few small teeth; hollow at apex of solenomere facing posteromedially, the anterior margin produced as small subapical tab with rounded notch medially on distal margin, the solenomere apex distal to the notch at right angles to the subapical tab. Prostatic groove running on anterior surface of telopodite and lateral to large, basal solenomere tab, following subapical tab margin and terminating at distal corner of subapical tab.

Female without process on leg 2 coxa.

\section{Distribution}

Known from eucalypt forest (and rainforest?) in northeast NSW from the ranges northwest of Coffs Harbour to the Comboyne district, a north-south extent of $c a .180 \mathrm{~km}$ (map Fig. 12). Overlaps in range with S. sulcatus. 


\section{Taxonomic notes}

The lectotype and paralectotype $S$. walesius males from North Dorrigo are almost identical in size and morphological details to the lectotype $P$. castaneum male from the Comboyne district, $150 \mathrm{~km}$ to the south; they differ slightly in the slenderness of the femorite (Fig. 11A-B). It is a little puzzling that Verhoeff did not recognise them as the same species. His drawings of the $S$. walesius telopodite tip (figs 26 and 27 in Verhoeff 1928; Fig. 11J ) appear to have been done from a posterior and slightly oblique view of the left gonopod of the lectotype, while the drawings of the P. castaneum telopodite tip (figs 6 and 7 in Verhoeff 1937; Fig. 11H) are from a medial view of the left gonopod telopodite on the lectotype slide mount. Verhoeff may have returned one of his $S$. walesius males to AM before he received the $P$. castaneum specimens, but he may still have held the male that found its way to ZMB. If not, it is possible that Verhoeff had no gonopod drawings of $S$. walesius to compare other than his published ones. Ironically, it was a comparison of those drawings that led Jeekel (2000) to propose that P. castaneum was a junior synonym of $S$. walesius.

In both S. walesius (Fig. 11C) and S. pruvoti (Fig. 11D) the solenomere tip ends in an L-shaped channel. One side of the ' $\mathrm{L}$ ' is the thin, anteroposteriorly flattened tab at whose medial margin the prostatic groove opens. The other, thicker side of the ' $\mathrm{L}$ ' is distal to this tab and lies in a plane at right angles to it. In S. pruvoti, a narrow notch (arrow in Fig. 11D) separates the two sides of the 'L', the distal side thus becoming a separate process, i.e., the 'pre-apical latero-distal process' of Jeekel (2000). In S. walesius, the two sides of the 'L' are joined at the tip by a shallow indentation (arrow in Fig. 11C). This difference does not seem to me to be important enough to separate two genera, which is why I have synonymised Parwalesoma with Solaenodolichopus (see above). In future papers I will document variations at the tip of the solenomere in other Solaenodolichopus species.

Verhoeff $(1928,1937)$ did not state how many specimens he examined, but gave male and female lengths for both $S$. walesius and $P$. castaneum. My lectotypifications imply that Verhoeff looked at two males and one female of $S$. walesius and two males (one dissected, most parts now missing) and two females of P. castaneum. However, the AM whole female in alcohol (KS.76509) and the ZSM male parts and whole female in alcohol (20052246) are missing any original Verhoeff labels. I include these among the types because I assume that the ZSM male parts are the remains of the male dissected for the ZSM slide mount, which does have a Verhoeff label, and because the collection details label for AM KS.76509 appears to be original. I have not made the male S. walesius in AM KS.94102 a paralectotype because it has only a recent, printed label; it may have been deposited directly in AM by collector E.C. Chisholm (see below). The ZSM slide of P. castaneum was labelled 'lectotype' by P.M. Johns in 1967, but this lectotypification was not published.

\section{General notes}

According to contemporary newspaper items, collector Dr E.C. Chisholm was a naturalist and Government Medical Officer in the Comboyne district from 1923 to 1935 (The Port Macquarie News and Hastings River Advocate, 4 Jun. 1927, p. 5, http://trove.nla.gov.au/ndp/del/article/ 112527391; The Sydney Morning Herald, 17 Jan. 1933, p. 6, http://trove.nla.gov.au/ndp/del/article/16945944; The Maitland Daily Mercury, 5 Jul. 1935, p. 3, http://rove.nla.gov.au/ndp/del/article/127096313; all accessed 24 Dec. 2013).

Chisholm presumably collected his Comboyne millipedes and sent them directly to Verhoeff (Verhoeff 1937: 133) during that 12-year period. As he had done with descriptions of NSW species in his 1928 paper, Verhoeff used the State museum journal, Records of the Australian Museum, as an outlet for his descriptions of $P$. castaneum and four other Comboyne millipede species. Verhoeff (1937) published in German, however, perhaps to avoid any misunderstandings arising from inadequate translation. 
See also the general notes for $S$. rubriventris (above).

\section{Discussion}

As circumscribed above, Solaenodolichopus is one of Australia's most speciose millipede genera (Car 2009; Mesibov 2008), and combined genetic and morphological studies will be needed to resolve its internal classification. Additional collecting and genetic studies will also be needed to satisfactorily delimit the suspiciously variable $S$. vittatus, and to clarify its relationship with $S$. pruvoti, from which it can currently only be distinguished by colour pattern.

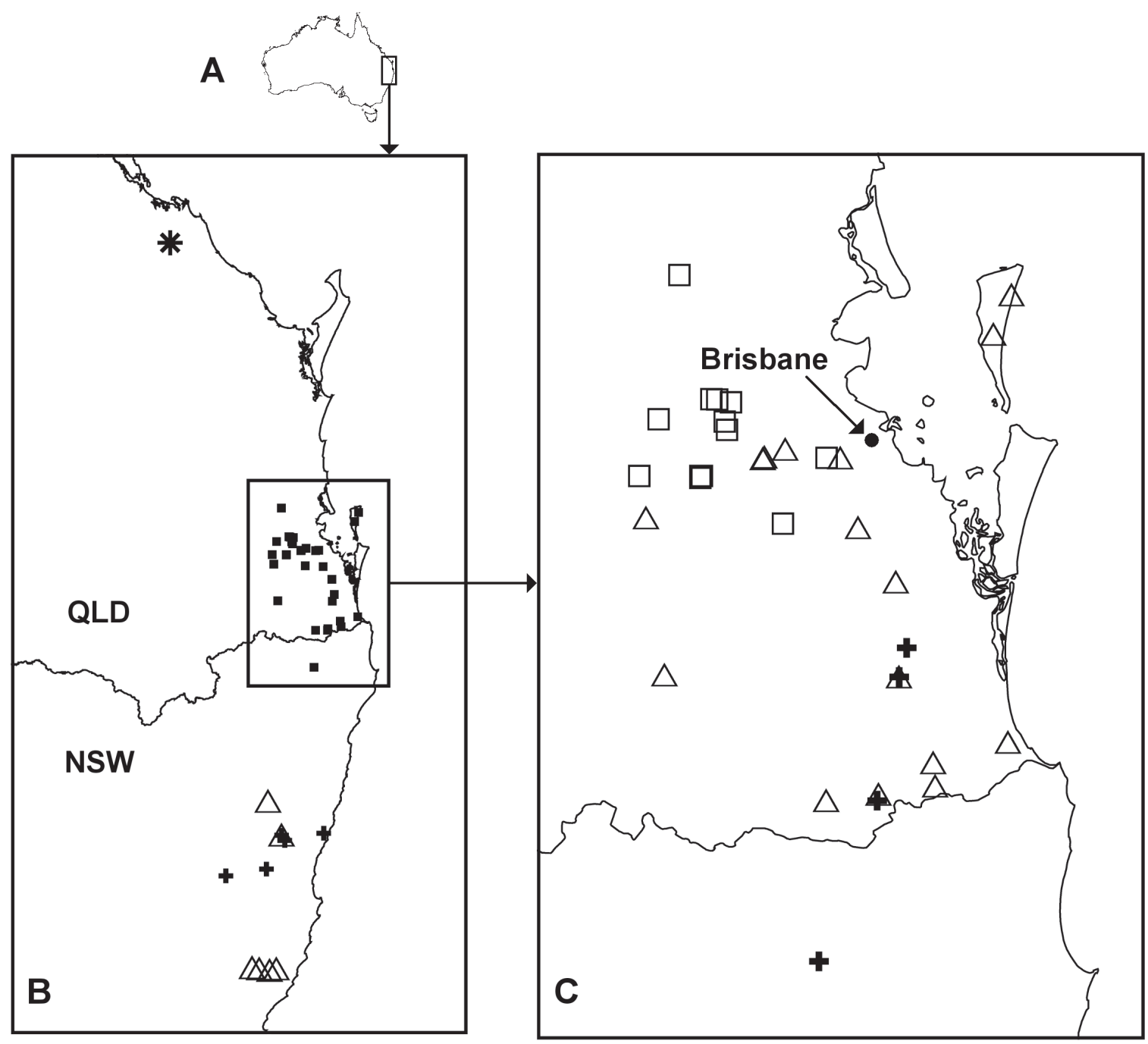

Fig. 12. Localities for named Solaenodolichopus species as of February 2014. - A. Australia showing location of map B (rectangle). - B. S. teres (Verhoeff, 1924) (star), S. sulcatus (Verhoeff, 1928) (crosses) and $S$. walesius Verhoeff, 1928 (open triangles), other species (filled squares); rectangle shows location of map C. - C. S. pruvoti (Brolemann, 1931) (open squares), S. rubriventris Verhoeff, 1928 (crosses) and S. vittatus (Verhoeff, 1924) (open triangles). Maps A-C are geographic projections; approximate north-south map extents are $900 \mathrm{~km}$ for B and $220 \mathrm{~km}$ for C. 
Phylogenetic work would also be desirable in the larger group of eastern Australian genera, evidently closely related, to which Aulacoporus, Solaenodolichopus and Walesoma belong. The known forms of Aulacoporus and Walesoma (described and undescribed) are separated by ca. $1300 \mathrm{~km}$, and this disjunction is unlikely to shrink with further collecting. The range of Solaenodolichopus (map Fig. 12) will expand considerably as new species are described and documented.

\section{Acknowledgements}

For loans of, or assistance with Verhoeff's types I am very grateful to Janet Beccaloni (Natural History Museum, London), Cathy Car (Western Australian Museum, Perth), Jason Dunlop (Museum für Naturkunde, Berlin), Jonas Ekström (Lund University, Lund), Karin Sindemark Kronestedt (Naturhistoriska Riksmuseet, Stockholm), Graham Milledge (Australian Museum, Sydney), Kate Sparks (South Australian Museum, Adelaide), Jörg Spelda (Zoologische Staatssammlung, München) and Verena Stagl (Naturhistorisches Museum, Vienna). I am especially grateful to Dr Åsa Ferrier (La Trobe University, Melbourne) for advice on Erik Mjöberg's Queensland expedition; to Margaret Henderson (Research Coordinator for the Richmond River Historical Society, Lismore, NSW) for advice on the Richmond River district; to Jean-Jacques Geoffroy (Muséum National d'Histoire Naturelle, Paris) for advice on H.W. Brolemann; and to Håkan Wittzell (Lund University Botanical Museum) and Jonas Ekstrom (Lund University Zoological Museum) for advice on Johan Mauritzon and his collections in Australia. I thank Sandrine Feig (University of Tasmania, Hobart) for assistance with SEM work. This study was funded by the author.

\section{References}

Attems C. 1911. Myriopoda exkl. Scolopendridae. In: Michaelsen W. \& Hartmeyer R. (eds) Die Fauna Südwest-Australiens. Ergebnisse der Hamburger südwest-australischen Forschungsreise 1905. Vol 3 (6): 1-393. Gustav Fischer Verlag, Jena.

Attems C. 1926. Myriopoda. In: Kükenthal W. \& Krumbach T. (eds) Handbuch der Zoologie. Eine Naturgeschichte der Stämme des Tierreiches. 4(1). Progoneata, Chilopoda, Insecta I: 1-402. Walter de Gruyter \& Co., Berlin and Leipzig.

Attems C. 1929. Diplopoden des Belgischen Congo. I. Polydesmoidea. Revue de zoologie et de botanique africaines 17 (3): 253-378.

Attems C. 1937. Das Tierreich. 68. Myriapoda. 3. Polydesmoidea. I. Fam. Strongylosomidae. Walter de Gruyter and Co., Berlin.

Attems C. 1940. Das Tierreich. 70. Myriapoda. 3. Polydesmoidea. III. Polydesmidae, Vanhoeffeniidae, Cryptodesmidae, Oniscodesmidae, Sphaerotrichopidae, Peridontodesmidae, Rhachidesmidae, Macellolophidae, Pandirodesmidae. Walter de Gruyter and Co., Berlin.

Brolemann H.W. 1931. Myriapodes recueillis par Madame Pruvot en Nouvelle-Calédonie et aux Loyalty. Archives de Zoologie Expérimentale et Générale 72: 275-316.

Car C.A. 2009. Keeled millipedes (Diplopoda: Polydesmida: Paradoxosomatidae) in New South Wales. General and Applied Entomology 38: 1-7. http://www.entsocnsw.org.au/images/stories/media/38\%20 carmillipedes.pdf

Car C.A., Wojcieszek J.M. \& Harvey M.S. 2013. The millipede genus Antichiropus (Diplopoda: Polydesmida: Paradoxosomatidae), part 1: redefinition of the genus and redescriptions of existing species. Records of the Western Australian Museum 28: 83-118.

Ferrier Å. 2006. Dr Eric Mjöberg's 1913 scientific exploration of North Queensland's rainforest region. Memoirs of the Queensland Museum Cultural Heritage Series 4 (1): 1-27. [Available online from 
MESIBOV R., Redescriptions of Solaenodolichopus millipedes

the Queensland Museum website, in 2013 as http://www.qm.QLD.gov.au/ /media/Documents/QM/ About\%20Us/Publications/Memoirs\%20-\%20Culture/C4-1/vol-4-1-ferrier.pdf]

Hedley C. 1915. Presidential address. Journal and Proceedings of the Royal Society of New South Wales 49:1-77. http://biodiversitylibrary.org/page/41688038

Jeekel C.A.W. 1965. A new genus and a new species of the family Paradoxosomatidae from Australia (Diplopoda, Polydesmida). Entomologische Berichten (Amsterdam) 25: 7-14.

Jeekel C.A.W. 1968. On the Classification and Geographical Distribution of the Family Paradoxosomatidae (Diplopoda, Polydesmida). C.A.W. Jeekel, Rotterdam.

Jeekel C.A.W. 1971. Nomenclator generum et familiarum Diplopodorum: A List of the genus and family-group names in the Class Diplopoda from the 10th edition of Linnaeus, 1758, to the end of 1957. Monografië̈n van de Nederlandse Entomologische Vereniging 5: i-xii, 1-412.

Jeekel C.A.W. 1981. Australia Expedition 1980; legit C.A.W. Jeekel and A.M. Jeekel-Rijvers. List of collecting stations, together with general notes on the distribution of millipedes in eastern Australia and Tasmania. Verslagen en Technische Gegevens, Instituut voor Taxonomische Zoölogie (Zoölogisch Museum), Universiteit van Amsterdam 30: 1-59.

Jeekel C.A.W. 1982. Millipedes from Australia, 1: Antichiropodini from South Australia (Diplopoda, Polydesmida, Paradoxosomatidae). Bulletin Zoölogisch Museum, Universiteit van Amsterdam 8 (14): 121-132.

Jeekel C.A.W. 2000. Millipedes from Australia, 12: Notes on the Paradoxosomatidae of New South Wales, with a key to the genera, and descriptions of a new genus and a new species (Diplopoda, Polydesmida). Myriapod Memoranda 2: 31-47.

Jeekel C.A.W. 2002. Millipedes from Australia, 14: A third contribution to the South Australian Paradoxosomatidae (Diplopoda, Polydesmida). Myriapod Memoranda 5: 60-77.

Mesibov R. 2008. Diversity of Queensland paradoxosomatid millipedes (Diplopoda: Polydesmida: Paradoxosomatidae). Australian Entomologist 35 (1): 37-46.

Musgrave A. 1932. Bibliography of Australian Entomology 1775-1930: with Biographical Notes on Authors and Collectors. Royal Zoological Society of New South Wales, Sydney.

Nguyen A.D. \& Sierwald P. 2013. A worldwide catalog of the family Paradoxosomatidae Daday, 1889 (Diplopoda: Polydesmida). Check List 9 (6): 1132-1353. [Available online through the journal website, http://www.checklist.org.br]

Verhoeff K.W. 1924. Results of Dr. E. Mjöberg's scientific expeditions to Australia 1910-1913. 34. Myriapoda: Diplopoda. Arkiv för Zoologi 16 (5): 1-142.

Verhoeff K.W. 1928. On Diplopoda in the Australian Museum, Sydney. Records of the Australian Museum 16 (2): 79-115, pls 6-12. [Available online through the Australian Museum website; as of Dec. 2013 at http://australianmuseum.net.au/Uploads/Journals/16815/782_complete.pdf]

Verhoeff K.W. 1932. Klasse Diplopoda. In: Dr H. G. Bronn's Klassen und Ordnungen des Tier-Reichs wissentschaftlich dargestellt in Wort und Bild. 5(II) 2(7-13). Gliederfüssler: Arthropoda: 1073-2084. Akademische Verlagsgesellschaft m.b.H., Leipzig.

Verhoeff K.W. 1937. Ueber einige neue Diplopoden aus Australien. Records of the Australian Museum 20 (2): 133-149. [Available online through the Australian Museum website; as of Dec. 2013 at http:// australianmuseum.net.au/Uploads/Journals/17264/257_complete.pdf]

Verhoeff K.W. 1941. Zur Kenntnis australischer Strongylosomiden und einiger anderen Diplopoden. Lunds Universitets Arsskrift (new series 2) 36 (17): 1-25. 
Manuscript received: 26 February 2014

Manuscript accepted: 2 April 2014

Published on: 15 May 2014

Topic editor: Rudy Jocqué

Desk editor: Kristiaan Hoedemakers

Printed versions of all papers are also deposited in the libraries of the institutes that are members of the EJT consortium: Muséum National d'Histoire Naturelle, Paris, France; Botanic Garden Meise, Belgium; Royal Museum for Central Africa, Tervuren, Belgium; Natural History Museum, London, United Kingdom; Royal Belgian Institute of Natural Sciences, Brussels, Belgium; Natural History Museum of Denmark, Copenhagen, Denmark. 